\title{
Proteomics Characterization of the Secretome from Rat Pancreatic Stellate Cells with ATP-Binding Cassette Transporters (ABCG2) and NCAM Phenotype
}

\author{
Maria Lucas, ${ }^{1}$ Eugenia Mato, ${ }^{1,2}$ Silvia Barceló-Batllori, ${ }^{1,3}$ \\ Ramon Gomis, ${ }^{1,4}$ and Anna Novials ${ }^{1,4}$ \\ ${ }^{1}$ Diabetes and Obesity Laboratory, August Pi i Sunyer Biomedical Research Institute (IDIBAPS), \\ Endocrinology and Nutrition Unit-Hospital Clínic, Barcelona, Catalonia, Spain \\ ${ }^{2}$ Biomedical Research Networking Centre on Bioengineering, Biomaterials \& Nanomedicine: CIBER-BBN-EDUAB-HSP Group, \\ Barcelona, Catalonia, Spain \\ ${ }^{3}$ Proteomics Unit, Cancer Epigenetics and Biology Program (PEBC), Bellvitge Biomedical Research Institute (IDIBELL), \\ Barcelona, Catalonia, Spain \\ ${ }^{4}$ Spanish Biomedical Research Centre in Diabetes and Associated Metabolic Disorders (CIBERDEM), Barcelona, Catalonia, Spain \\ Correspondence should be addressed to Eugenia Mato; emato@santpau.cat and Anna Novials; anovials@clinic.ub.es
}

Received 1 July 2013; Accepted 4 August 2013

Academic Editors: A. Hergovich and A. A. Minin

Copyright (C) 2013 Maria Lucas et al. This is an open access article distributed under the Creative Commons Attribution License, which permits unrestricted use, distribution, and reproduction in any medium, provided the original work is properly cited.

\begin{abstract}
We have previously reported the identification of a pancreata mitoxantrone-resistant cell population which expressed the ABCG2 transporter with a pancreatic stellate cells phenotype (PaSC) and ability of secreting insulin after inducing their differentiation. The characterization of the secretome of this cell population by two-dimensional electrophoresis (2D) coupled with mass spectrometry MALDI-TOF was able to identify seventy-six protein spots involved in different cellular processes: development/differentiation, proteases, immune response, and other. Moreover, Ingenuity Pathway Analysis displayed several significant networks and TGF $\beta 1$ molecule was identified as a central node of one of them. The effect of this active molecule secreted in the conditioned medium was investigated in ductal cell line (ARIP). The results showed that the conditioned medium inhibited their proliferation without affecting their cell viability. Additionally, they showed an upregulation of PDX1 and downregulation of CK19. The rate of ARIP cell proliferation was recovered, but no effects on the gene expression were observed after using TGF $\beta 1$-neutralising antibody. Proteins associated with cell growth, development and differentiation such as PEDF, LIF, and Wnt5b, identified in the secretome, could be involved in the observed transcription changes. These finding may suggest a new paracrine action of PaSCs involved in the proliferation and differentiation pathways not yet identified.
\end{abstract}

\section{Introduction}

Pancreatic stellate cells (PaSC) were first described in 1998 and constitute nearly $4 \%$ of total pancreatic cells [1]. PaSCs are located in the periacinar space and can also be found in the periductal regions of the pancreas [2]. These cells have long cytoplasmatic processes resulting in a typical "stellate" appearance. They share morphological and functional characteristics with the hepatic stellate cells and can present different phenotypes: quiescent cells, with capacity to storage vitamin $\mathrm{A}$, and active cells, also so-called myofibroblast-like cells. The active phenotype expresses alpha actin (aSMA), desmin, glial fibrillary acidic protein (GFAP), ABCG2, and NCAM. These latter two markers are expressed in rat and human hepatic stellate cells, and several studies demonstrate that NCAM is involved in the transformation of these cells in myofibroblasts and modulates the adhesive property of cell adhesion [3], and ABCG2 transporter is associated with cell viability and/or activation [4]. They can be useful to select PaSC with a myofibroblast phenotype. Moreover, several studies demonstrated that the soluble factors secreted by PaSCs with active phenotype, which are increased in areas 
of pancreatic injury, play an important role in pancreas physiology, development of pancreatic fibrosis [5], antigen presentation, phagocytosis phenomena [6], and matrix turnover processes [7].

It is known that endocrine pancreatic tissue is able to regenerate in several species of mammals, including humans. Several studies support the hypothesis that this islet neogenesis in the mature pancreas occurs via cells which are located in or which are associated with the ductal epithelium. Ductal cells have the capacity to transdifferentiate into insulin producing cells, both in animal models and humans [8-11]. The role of surrounding cells may be important in maintaining their cellular niche, giving them the necessary factors to start the transdifferentiation process. Considering that PaSCs are also present in the same niche as ductal cells, for instance, periacinar and periductal regions, it is likely that PaSC secreted factors could have effects on neighbouring cells, as well as on the putative pancreatic progenitors.

The present study was designed to characterize the secretome of mitoxantrone-resistant cells obtained from lactating rats pancreata expressing the ABCG2 transporter and NCAM markers, with a PaSC phenotype (PaSCs-ABCG2(+)) and ability to secrete insulin after differentiation [12].

\section{Materials and Methods}

2.1. Primary Cell Culture of Mitoxantrone-Resistant Cells Expressing Active Pancreatic Stellate Cells Phenotype Obtained by Drug Section and Enriched by PSA-NCAM Immunopanning Technique. All animal experimental proceeds were approved by the Institutional Animal Care and Use Committee of the IDIBAPS Research Institute, Barcelona, Spain. Fresh pancreata were removed from lactating rats and digested with collagenase to obtain a primary cell culture. This culture was grown in Dulbecco's Modified Eagle Medium (DMEM) (Gibco-BRL, Gaithersburg, MD, USA) ( $25 \mathrm{mM}$ of glucose) supplemented with $10 \%$ fetal calf serum (FCS), and $100 \mathrm{U} / \mathrm{mL}$ of penicillin and mitoxantrone drug at $8 \mu \mathrm{M}$ (Sigma-Aldrich St. Louis, MO, USA) was added to the medium. This drug acts through multidrug transporter systems and permits the selection of cells which express the ABCG2 transporter, as described by Mato et al. [12]. The culture was maintained at $37^{\circ} \mathrm{C}$ in a humidified atmosphere containing $5 \% \mathrm{CO}_{2}$ and was expanded and the active pancreatic stellate cell phenotype was checked by immunocharacterization (alpha-actin, vimentin, desmin, chromogranin A, GFAP, and NCAM), RT-PCR expression (ABCG2), or oilred staining as described by Mato et al. [12]. It is known that in mammals, PSA-NCAM is involved in the development of the nervous system and in tissue remodeling [13] and it also can induce proliferation in activated pancreatic stellate cells. In order to enrich active stellate cells fraction in our primary culture, we performed immunopanning as previously described by Ben-Hur et al. [14] using the sialylatedneural adhesion molecule isoform of NCAM (PSA-NCAM). Petridishes (Falcon Optilux) were first coated with secondary antibody IgM (Sigma-Aldrich) at $1: 128$ in $50 \mathrm{mM}$ Tris- $\mathrm{HCl}$ buffer, $\mathrm{pH} 9.5$, for 18 hours at $4^{\circ} \mathrm{C}$. The plates were then washed three times in PBS and coated with anti-PSA-NCAM antibody (USBiological, Swampscott, MA, USA) at 1:250 dilution in PBS with $0.2 \%$ BSA at room temperature for at least 1 hour. Cells were plated at $1 \times 10^{6}$ cells $/ 100 \mathrm{~mm}$ dish coated for PSA-immunopanning and were allowed to bind at $37^{\circ} \mathrm{C}$ for 30 minutes. Nonadherent cells, so-called negative fraction, were washed off extensively to discard them. The adherent cells corresponded to the positive fraction that expressed that PSA-NCAM were trypsinised, washed three times, and resuspended in fresh DMEM-F12, and a second PSA-NCAM immunopanning was redone. Before using the positive fraction of the cell in different experiments, the pancreatic stellate cell phenotype was confirmed by immunocytochemistry and flow cytometry each time. After the second immunopanning (positive PSA-NCAM fraction) conditioned media from active PaSCs-ABCG2(+) were collected every 48 hours and frozen at $-80^{\circ} \mathrm{C}$ until used for subsequent analysis. For proteome analysis, conditioned media were collected as described: active PaSCs-ABCG2(+) cells were washed 3 times in PBS and cultured in serum-free media for 24 hours. This media was collected and centrifuged at $5000 \mathrm{~g}$ for 10 minutes to remove cell debris, after which the supernatant was frozen at $-80^{\circ} \mathrm{C}$ until use.

2.2. Flow Cytometry. One million PBS-washed cells were resuspended in $875 \mu \mathrm{L}$ of cold PBS. Then, $125 \mu \mathrm{L}$ of cold $2 \%$ formaldehyde solution was added and the mixture was immediately vortexed for a brief period. The suspension was incubated for 1 hour at $4^{\circ} \mathrm{C}$ and centrifuged for 5 minutes at $250 \mathrm{~g}$, after which the supernatant was removed. The pellet was gently resuspended in $1 \mathrm{~mL}$ of cold blocking solution (0.2\% BSA in PBS), and the mixture was incubated for 1 hour at $4^{\circ} \mathrm{C}$. One $\mathrm{mL}$ of buffer was added and the suspension was spun down for 5 minutes at $250 \mathrm{~g}$. The supernatant was removed, and $50 \mu \mathrm{L}$ of primary antibody PSA-NCAM (USBiological) was added at a dilution 1:10 in blocking solution. The sample was incubated overnight at $4^{\circ} \mathrm{C}$ in the dark, washed twice with $1 \mathrm{~mL}$ of PBS by centrifugation at $250 \mathrm{~g}$ for 5 minutes, and resuspended in $500 \mu \mathrm{L}$ of secondary antibody (IgM, Sigma-Aldrich) at a dilution 1:128 in blocking solution. After 1 hour of incubation at $4^{\circ} \mathrm{C}$, samples were washed twice with $1 \mathrm{~mL}$ of PBS by centrifugation at $250 \mathrm{~g}$ for 5 minutes and resuspended in $500 \mu \mathrm{L}$ of PBS. The labelled cells were analysed on a FACS Calibur (BD, San Jose, CA, USA) by acquisition of 10,000 gated events. Data was stored as listmode files and analysed with CellQuest (BD) and Summit Workstation software.

2.3. ARIP Cell Culture and Treatment. ARIP cell line were obtained from ATCC (CRL-1674 clon) and cultured in ARIP media: DMEM $24 \mathrm{mM}$ glucose plus glutamine, nonessential amino acids, $100 \mathrm{U} / \mathrm{mL}$ of penicillin, and 10\% FCS. Cells were treated with PaSC conditioned media for 24 or 72 hours. DMEM/F12 (8 mM glucose) supplemented with 10\% FCS (PaSCs ABCG2(+) media) were used as basal media. All the experiments were performed using low passages from 16 to 19 of the cell culture.

2.4. Proliferation and Viability Assays. ARIP cells were seeded in 96-well tissue culture plates at a density of 50,000 cells/well 
and incubated for 24 hours until adherence. Cells were then incubated in serum-free DMEM overnight and exposed to $15 \%$ FCS for 24 hours. Cells were either treated with pan TGF $\beta 20 \mu \mathrm{g} / \mathrm{mL}$ (R\&D Systems, Minneapolis, MN, USA), TGF $\beta 110 \mathrm{ng} / \mathrm{mL}$ (R\&D Systems), or nonimmune IgG $20 \mu \mathrm{g} / \mathrm{mL}$ (Dako, Glostrup, Denmark), with the final 4 hours in the presence of $10 \mu \mathrm{M}$ BrdU. BrdU incorporation into ARIP cell DNA was assessed by measuring the absorbance at $450 \mathrm{~nm}$, following cell proliferation ELISA kits instructions (Roche, Penzberg, Germany).

To conduct the viability assays, ARIP cells were seeded in 96-well tissue culture plates at a density of 50,000 cells/well and incubated for 24 hours until adherence. Cells were then incubated in serum-free DMEM overnight and exposed to $15 \%$ FCS for 24 hours, with the final 2 hours in the presence of $0.5 \mathrm{mg} / \mathrm{mL}$ MTT (Sigma-Aldrich, St. Louis, Missouri). Finally, $115 \mu \mathrm{L}$ of isopropanol plus $0.04 \mathrm{~N} \mathrm{HCl}$ was added, samples were mixed well to dissolve crystals, and absorbance was measured at $575 \mathrm{~nm}$.

2.5. RT-PCR. Total RNA was extracted from ARIP cultures using TRIzol reagent (Invitrogen, Carlsbad, CA, USA). To remove genomic DNA contamination, samples were treated with DNase I (Invitrogen), following the manufacturer's instructions. In addition, DNA-PCR without RT was included as a control. One $\mu$ g of total RNA was reverse transcribed in a buffer solution containing $25 \mathrm{nmol} / \mathrm{L}$ $\mathrm{MgCl}_{2}, 100 \mathrm{mmol} / \mathrm{L}$ Tris (pH 8.3), $500 \mathrm{mmol} / \mathrm{L} \mathrm{KCl}$, RNAguard $39 \mathrm{U} / \mathrm{mL}$ (Pharmacia, Uppsala, Sweden), M-MLVRT $200 \mathrm{U} / \mathrm{mL}$ (Gibco, Uxbridge, UK), $10 \mathrm{mmol} / \mathrm{L}$ deoxynucleotide triphosphate(s), and random hexamer priming d(N6)5'PO4 (Pharmacia). Complementary DNA (cDNA) was stored at $-80^{\circ} \mathrm{C}$ until use. All PCRs were performed using 35 cycles. PCR products were visualised with $1 \%$ agarose gel electrophoresis and ethidium bromide staining.

2.6. Real-Time PCR. Real-time PCR was performed using the double stranded DNA binding dye Power SYBR Green PCR Master Mix using the ABI Prism 7900HT Sequence Detection System (Applied Biosystems, Foster City, California, USA). The sequences of primers used in this study are described in Table 1. A standard curve was generated from five serial dilutions of ARIP cDNA for CK19 and INS1E cDNA for PDX1. Samples were analysed in triplicate, negative controls were included, and PCR products were verified using dissociation curve analysis immediately after RT-PCR. Expressions of all target genes were determined by normalising the respective TATA Binding Protein (TBP) levels as a housekeeping gene. Results were analysed using SDS2.1 software (Applied Biosystems).

The oligonucleotide sequences used for PCR and realtime PCR amplification are summarised in Table 1.

2.7. Immunocharacterization of PDX1 and CK19. ARIP cells were plated in 8-well chamber slides (LAB-TEK, Campbell, CA, USA). After treatment with control or conditioned media for 72 hours, cells were fixed in $4 \%$ paraformaldehyde. They were then blocked for 10 minutes at room temperature in
$1 \%$ BSA and then permeabilized with buffer containing $1 \%$ BSA and $0.2 \%$ saponin for 30 minutes at room temperature. Primary antibodies (PDX1-1:100, Santa Cruz, Santa Cruz, CA, USA; CK19-1:500, Dako) were diluted in fresh blocking solution, and the slides were then incubated overnight at $4^{\circ} \mathrm{C}$ following standard protocols. The reaction was visualised with a fluorescent secondary antibody $(1: 1000)$ under a Leica fluorescence microscope. $1 \%$ BSA was used instead of primary antibodies for control slides.

2.8. Characterisation of the Secreted Proteins from the Active PaSC-ABCG2(+) Conditioned Media. Conditioned media and serum-free conditioned media were collected as described before. Culture media alone (basal) were used as a blank and were also incubated without cells during 24 hours and collected. Centricon Amicon (Millipore, MA, USA) centrifugal filters with a $10 \mathrm{KDa}$ molecular weight cutoff were used to concentrate conditioned media from $10 \mathrm{~mL}$ to $200 \mu \mathrm{L}$, following the manufacturer's instructions. Proteins were precipitated using the 2D Clean Up Kit (GE Healthcare, United Kingdom) and were resuspended in a solution containing Tris $(30 \mathrm{mM})$, urea $(7 \mathrm{M})$, thiourea $(2 \mathrm{M})$, and CHAPS (4\%) compatible with first dimension isoelectric focusing (IEF). Protein content was quantified using the RC DC protein assay kit (BioRad, Hercules, CA, USA) based on the Lowry assay.

Protein extracts $(100 \mu \mathrm{g})$ were separated using IPG strips of pH 3-10 (17 cm, BioRad). Two-dimensional electrophoresis was carried out [15]. Briefly, isoelectric focusing was performed in Protean IEF Cell (Biorad) at $62 \mathrm{kVh}$ and second dimension SDS-PAGE were run by overlaying the strips on $12 \%$ acrylamide home-made gels. Proteins were visualised using a MS compatible silver stain [16]. Gels were calibrated using MW and pI standards (Biorad). Differential expression of proteins from blank, conditioned media and serum-free conditioned media were analysed using MelanieIII software (BioRad). First, conditioned media and serumfree conditioned media were compared to ensure that serum was not affecting the secretome pattern. Proteins present in the conditioned media (both serum and serum-free), but absent in blank media, were considered as PaSC secreted. Secreted proteins were excised from serum-free conditioned media gels $(n=5)$, silver destained and in-gel digested with trypsin (Promega, Madison, WI, USA) $37^{\circ} \mathrm{C}$ overnight. Peptide extraction was performed and Zip-Tip concentrating and desalting was done [17]. Peptides were analysed by MALDI-TOF MS and proteins were identified by peptide mass fingerprinting [18].

\subsection{Amino Acid Sequence Search for Features of Secreted} Proteins. The amino acid sequence of the identified proteins was analysed with SecretomeP 2.0 Server. SignalP 3.0, which predicts the presence and location of signal peptide cleavage sites in the $\mathrm{N}$-terminal part (first 70 residues), identified proteins secreted via the classical pathway [19]. If no signal peptide was predicted, but the Neural Network score exceeded a value of 0.5 , proteins were classified as secreted via the nonclassical pathways. SignalP 3.0 has been used to identify secreted proteins in other secretome studies [20,21]. 
TABLE 1: List of all the primers used in this study.

\begin{tabular}{|c|c|c|c|c|c|}
\hline Name & Sequence & bp & $\mathrm{F} / \mathrm{R}$ & $T$ annealing & GenBank accession numbers \\
\hline \multirow{2}{*}{ Calreticulin } & GGGCCCCTGATACCAAATGTC & \multirow{2}{*}{467} & FW & \multirow{2}{*}{$57^{\circ} \mathrm{C}$} & \multirow{2}{*}{ XM_001067664 } \\
\hline & CTCTCGCCGCTGCCTTCC & & RV & & \\
\hline \multirow{2}{*}{ Wnt5b } & GCGCTGCTGGTGTGGTGAATG & \multirow{2}{*}{415} & FW & \multirow{2}{*}{$60^{\circ} \mathrm{C}$} & \multirow{2}{*}{ XM_342747 } \\
\hline & CCGGGCTGGGCTGGTTGA & & RV & & \\
\hline \multirow{2}{*}{ Calumenin } & AGCTCCGGGGAAAACTCAG & \multirow{2}{*}{501} & FW & \multirow{2}{*}{$60^{\circ} \mathrm{C}$} & \multirow{2}{*}{ NM_022535 } \\
\hline & CTCCGCTCATCTCTAACCATAATC & & $\mathrm{RV}$ & & \\
\hline \multirow{2}{*}{ SPARC } & AAACCCCTGCCAGAACCATCATTG & \multirow{2}{*}{415} & FW & \multirow{2}{*}{$60^{\circ} \mathrm{C}$} & \multirow{2}{*}{ NM_012656 } \\
\hline & CTCCAGGCGCTTCTCGTTCTCGTG & & RV & & \\
\hline \multirow{2}{*}{ DIXDC1 } & GGGCAAATATGGATAAGGATGAGC & \multirow{2}{*}{435} & FW & \multirow{2}{*}{$57^{\circ} \mathrm{C}$} & \multirow{2}{*}{ NM_001037654 } \\
\hline & GTGACCGCCCCCGAACC & & RV & & \\
\hline Neuromodulin (GAP 43) & CTCCCGTTGCTGATGGTGTGG & 453 & FW & $60.5^{\circ} \mathrm{C}$ & NM 017195 \\
\hline 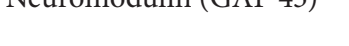 & GGTCAGCCTCGGGGTCTTCTTTAC & & RV & - & 1VIVI_UITISO \\
\hline Synaptotaomin V & CAGGGCAGAACACGCACGCACATA & 524 & FW & $59^{\circ} \mathrm{C}$ & BC 092198 \\
\hline (5y & CTCCGGCCCAGCTCCTTCACTTCC & & RV & & DC- \\
\hline Transcobalamin 2 & TGGGCCAGCGTCTCTTACCTT & 508 & FW & $60.5^{\circ} \mathrm{C}$ & NM_022534 \\
\hline Iranscodalamm 2 & CCGGCCATGGCTTCTGTGTC & 500 & $\mathrm{RV}$ & 00.30 & N1VI_02Z354 \\
\hline PEDF (serpin F1) & GGAGCCCGTAGTGGAGGAGGATGA & 417 & FW & $60^{\circ} \mathrm{C}$ & BC_078686 \\
\hline & ATGCGAGGGTTGCCAGTGAGGATT & 417 & RV & & DC_- $7 / 0000$ \\
\hline AHNAK & GTCGGCTCCTCAAGTCTCCATACC & 482 & FW & $57^{\circ} \mathrm{C}$ & XR 005457 \\
\hline AN10 & TCCCCGACACTTTCACACCATCT & 702 & RV & & 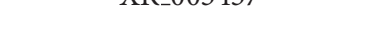 \\
\hline DHRS4 & AGGCGGCTCGGTGGTGATT & 441 & FW & $58^{\circ} \mathrm{C}$ & NM 153315 \\
\hline & TGGCGGTGGCAAGGAAGG & & RV & $50 \mathrm{C}$ & NIV_IJSJIJ \\
\hline Glypican 1 variant & GCTGCTGCTGCCCGATGACTAT & 489 & FW & $61^{\circ} \mathrm{C}$ & NM 030828 \\
\hline Glypican i vantant & CCGCAGCCCTGGATGACCTTA & 409 & RV & O1 C & NIV1_UJU020 \\
\hline RAB15 & GCCGGGCCGCTTCCTTCT & 404 & FW & $61^{\circ} \mathrm{C}$ & NM 198749 \\
\hline TH & GCGCTCGCTGCTAATGTCGTA & 704 & RV & 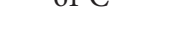 & 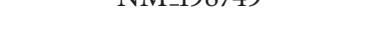 \\
\hline ARHGEF2 & AGACCCGGGAAAAGGAGAAGATGA & 445 & FW & $58^{\circ} \mathrm{C}$ & NM 001012079 \\
\hline & TGACGCAGCCCCAGAGGAGAC & & RV & & \\
\hline Islet cell autoantioen 1-like & TCGGTTTGCTCAAGATAAGTCAGT & 404 & FW & $545^{\circ} \mathrm{C}$ & NM 030844 \\
\hline 1stet cen autoanugen 1-nke & TGGCCCGATGTCTAAAAGTCTCTA & 404 & RV & $34.3 \mathrm{C}$ & NIVI_UJ0844 \\
\hline Leukemia inhibitory factor & AGGTCTTGGCCGCAGGGATTG & 508 & FW & $58^{\circ} \mathrm{C}$ & NM 022196 \\
\hline & TCGGGGACACAGGGCACAT & 508 & $\mathrm{RV}$ & $20 \mathrm{C}$ & N1V1_0Z2190 \\
\hline ERABP & CATGGTGGTCGAGCTGAAAGAGAA & 448 & FW & $55^{\circ} \mathrm{C}$ & NM 024136 \\
\hline & GTAGGGAAGGAGAGGCCAGGTAGG & & RV & & \\
\hline RAB14 & TCGGGGATATGGGAGTAGGAA & 541 & FW & $54.5^{\circ} \mathrm{C}$ & NM 053589 \\
\hline & GGGGCTGAGGGTTTGTGTTGTA & & RV & & \\
\hline APG16 autophagy 16-like & CGGCCACAGCGGGAAAGTT & 542 & FW & $58^{\circ} \mathrm{C}$ & XM 001067061 \\
\hline & CCCACGCCACCGCATTGATAGAAG & & RV & & \\
\hline MMP2 & GCTGATACTGACACTGGTACTG & 217 & FW & $60^{\circ} \mathrm{C}$ & NM 031054 \\
\hline & CAATCTTTTCTGGGAGCTC & & $\mathrm{RV}$ & & \\
\hline Collagen I & GCCACCTCAAGAGAAGTC & 440 & FW & $58.5^{\circ} \mathrm{C}$ & BC133728.1 \\
\hline & ATAGCGACATCGGCAGGATCG & & RV & & \\
\hline Vimentin & GCCAGCAGTATGAAAGTGTG & 496 & FW & $60^{\circ} \mathrm{C}$ & NM 031140 \\
\hline & AGTGGGTGTCAACCAGAGGAA & & RV & & \\
\hline Desmin & AGACTTGACTCAGGCAGCCAAT & 384 & FW & $60^{\circ} \mathrm{C}$ & NM 022531 \\
\hline Desinitit & CGGAAGTTGAGAGCAGAGAAGG & 307 & $\mathrm{RV}$ & 0 & 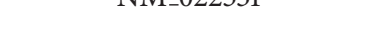 \\
\hline GFAP & TGGCCACCAGTAACATGCA & 538 & FW & $60^{\circ} \mathrm{C}$ & NM 017009 \\
\hline & GACTCCTTAATGACCTCGCCAT & & $\mathrm{RV}$ & & \\
\hline TBP & ACCCTTCACCAATGACTCCTATG & 190 & FW & 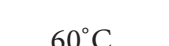 & NM 001004198 \\
\hline $10 \mathrm{Dr}$ & ATGATGACTGCAGCAAATCGC & 190 & RV & & \\
\hline PDX1 & GAGCCCAGCCGCGTTCATCT & 318 & FW & $60^{\circ} \mathrm{C}$ & NM 022852 \\
\hline & CCCCGCTCGTTGTCCCGCTACTA & & RV & & \\
\hline
\end{tabular}


TABle 1: Continued.

\begin{tabular}{|c|c|c|c|c|c|}
\hline Name & Sequence & $\mathrm{bp}$ & $\mathrm{F} / \mathrm{R}$ & $T$ annealing & GenBank accession numbers \\
\hline \multirow{2}{*}{ CK19 } & ACAGCCAGTACTTCAAGACC & \multirow{2}{*}{690} & FW & \multirow{2}{*}{$57^{\circ} \mathrm{C}$} & \multirow{2}{*}{ AY_464140 } \\
\hline & CTGTGTCAGCACGCACGTTA & & $\mathrm{RV}$ & & \\
\hline \multirow{2}{*}{ RTGFB I } & ACCGCGTGCCAAATGAAGAGGAT & \multirow{2}{*}{464} & FW & \multirow{2}{*}{$55^{\circ} \mathrm{C}$} & \multirow{2}{*}{ L26110.1 } \\
\hline & TGCCGTGGACAGAGCGAGTTTGAT & & RV & & \\
\hline \multirow{2}{*}{ RTGFB II } & TGGCCGCTGCACATCGTCCTG & \multirow{2}{*}{366} & FW & \multirow{2}{*}{$55^{\circ} \mathrm{C}$} & \multirow{2}{*}{ AF474028.1 } \\
\hline & CTCGCCCGCCCTTTTCTTTTCCTT & & $\mathrm{RV}$ & & \\
\hline \multirow[t]{2}{*}{ RTGFB III } & AGCAGCGCGGCCCACAGCATC & \multirow[t]{2}{*}{531} & FW & \multirow[t]{2}{*}{$55^{\circ} \mathrm{C}$} & \multirow{2}{*}{ NM_017256.1 } \\
\hline & GAAGGGGGCATCCAGGGCGAGACT & & RV & & \\
\hline \multirow{2}{*}{ TBP real time } & TTCGTGCCAGAAATGCTGAA & & FW & & \multirow{2}{*}{ NM_001004198 } \\
\hline & GTTCGTGGCTCTCTTATTCTCATG & & RV & & \\
\hline \multirow{2}{*}{ PDX1 real time } & CCGCGTTCATCTCCCTTTC & & FW & & \multirow{2}{*}{ NM_022852 } \\
\hline & CTCCTGCCCACTGGCTTTT & & $\mathrm{RV}$ & & \\
\hline CK19 real time & AAGGTCCAGGACCTTGAGATTG & & FW & & AY_464140 \\
\hline
\end{tabular}

2.10. Detection of TGF $\beta 1$ in the Conditioned Media. For TGF $\beta 1$ detection, conditioned media were collected as for proteome analysis. One hundred $\mu \mathrm{L} /$ well of the capture antibody (R\&D Systems, Minneapolis, MN, USA) diluted $2 \mu \mathrm{g} / \mathrm{mL}$ in PBS was transferred to an ELISA plate and incubated overnight at room temperature. Five separate washing were performed. In the first washing of three times with PBS $0.05 \%$ Tween 20, the plate was blocked with PBS containing 5\% Tween 20 and 5\% sucrose for 1 hour. In the second washing of three times with PBS $0.05 \%$ Tween $20,100 \mu \mathrm{L}$ of samples (conditioned media) and dilutions of standards of recombinant human TGF $\beta 1$ (R\&D Systems) were added and incubated for 2 hours at room temperature. In the third washing of three times with PBS $0.05 \%$ Tween 20 , $100 \mu \mathrm{L}$ of detection antibody biotinylated anti-TGF $\beta 1$ (R\&D Systems) at $400 \mathrm{ng} / \mathrm{mL}$ was added and incubated 2 hours at room temperature. In the fourth washing of three times with PBS $0.05 \%$ Tween $20,100 \mu \mathrm{L}$ of streptavidin HRP was added for 20 minutes at room temperature. In the final washing of three times with PBS $0.05 \%$ Tween $20,100 \mu \mathrm{L}$ of substrate solution was added for 30 minutes, avoiding placing the plate in direct light. $50 \mu \mathrm{L}$ of $1 \mathrm{M} \mathrm{H}_{2} \mathrm{SO}_{4}$ was added to each well and absorbance was measured at $450 \mathrm{~nm}$.

2.11. Statistical Analysis. Results are expressed as mean \pm SEM; $n$ represents the number of individual PaSC-ABCG2+ preparations. The statistical significance of the differences between groups was estimated using Student's unpaired $t$ test; ${ }^{*}$ indicate statistical significance with $P<0.05$.

\section{Results}

3.1. Immunopanning PSA-NCAM Enrichment from PaSCABCG2(+) Primary Culture. Flow cytometry PSA-NCAM analysis of mitoxantrone-resistant cells maintained in the basal cell culture condition described before showed a $36 \%$ of positivity for this marker. In order to conduct the secretome analysis, we enriched the cell population for polysialylated isoforms of the neural cell adhesion molecule (PSA-NCAM) by immunopanning technique, showing an increase of $57 \%$ of PSA-NCAM positivity in the first immunopaning up to $80 \%$ when the second immunopanning was redone. Then we confirm the active pancreatic stellate phenotype by immunocharacterization and ABCG2 expression each time (data not shown).

3.2. Secretome Analysis of PaSC-ABCG2(+). Conditioned media were prepared from active PaSC-ABCG2(+) cultured in serum-free conditions and subjected to 2-dimensional gel electrophoresis and silver staining. A preliminary study showed no differences in the secretion pattern between conditioned media and serum-free conditioned media. We decided to use serum-free conditioned media in order to eliminate serum-derived proteins from the media and to potentiate the less abundant proteins secreted from this cell population. The conditioned media $2 \mathrm{D}$ gels displayed a mean of 112 protein spots, which were selected for trypsin digestion and mass spectrometry MALDI-TOF analysis, and 76 spots were identified. Figure 1(a) is a representative image showing a $2 \mathrm{D}$ gel from PaSC-ABCG2 $(+)$ conditioned media with all the proteins identified. The majority of spots contained only single proteins, but in some cases MS analyses indicated a protein mixture. On the other hand, multiple spots flagged the same protein identity, thus suggesting posttranslational modifications or different isoforms. Overall, 61 different proteins were identified in the PaSC-ABCG2(+) secretome. Proteins along with Swiss-Prot accession number, annotations regarding prediction of secretion, and information related to peptide mass fingerprinting identification are listed in Table 2. Functional categories of the identified protein were proteolysis and related proteins, structural and cytoskeleton proteins, associated with cell growth, development, and differentiation, chaperones, metabolism, transport proteins, GTPase-related proteins, immune response, extracellular matrix and related proteins, and retinol related proteins. The identified proteins were analysed with SignalP V3 software which has been used to predict potential protein secretion $[20,21]$. Sixty-one percent of the proteins were predicted to 
TABLE 2: List of the proteins obtained in the secretome of PaSCs-ABCG2(+).

\begin{tabular}{|c|c|c|c|c|c|c|c|c|c|}
\hline Protein number & Protein name & UniProt ID & $\mathrm{pI}(\mathrm{T})$ & MW (T) & $\mathrm{pI}(\mathrm{E})$ & MW (E) & n.pep & $\% \operatorname{Cov}$ & Secretion \\
\hline \multicolumn{10}{|c|}{ Proteolysis and related proteins } \\
\hline 1 & Procollagen C-endopeptidase enhancer 1 & O08628 & 8,2 & 48000 & 7,1 & 55793 & 8 & 18 & 1 \\
\hline 1 & Procollagen C-endopeptidase enhancer 1 & O08628 & 8,2 & 48000 & 7,6 & 55793 & 7 & 18 & 1 \\
\hline 1 & Procollagen C-endopeptidase enhancer 1 & O08628 & 8,2 & 48000 & 6,7 & 56509 & 11 & 33 & 1 \\
\hline 1 & Procollagen C-endopeptidase enhancer 1 & O08628 & 8,2 & 48000 & 6,2 & 57108 & 10 & 28 & 1 \\
\hline 2 & 72 kDa type IV collagenase (MMP2) & P33436 & 5,1 & 62000 & 5,0 & 68834 & 16 & 26 & 1 \\
\hline 3 & Alpha-2 antiplasmin & Q80ZA3 & 6 & 46000 & 5,5 & 52395 & 10 & 28 & 1 \\
\hline 3 & Alpha-2 antiplasmin & Q80ZA3 & 6 & 46000 & 5,4 & 53373 & 9 & 26 & 1 \\
\hline 4 & $\begin{array}{c}\text { Isoform } 4 \text { of ubiquitin carboxyl-terminal } \\
\text { hydrolase } 15\end{array}$ & Q8R5H1-4 & 5,4 & 26000 & 5,3 & 31776 & 8 & 38 & 2 \\
\hline 5 & $\begin{array}{l}\text { Adult male cDNA proteasome regulatory } \\
\text { particle }\end{array}$ & Q8C1T2 & 4,9 & 28000 & 4,9 & 31776 & 5 & 22 & 3 \\
\hline 6 & Cathepsin B. & Q6IN22 & 5,5 & 38000 & 5,1 & 42629 & 6 & 23 & 1 \\
\hline 7 & ATPase 3 (Fragment) & Q6PW16 & 6,2 & 14000 & 7,1 & 27988 & 7 & 57 & 2 \\
\hline \multicolumn{10}{|c|}{ Structural and cytoskeleton proteins } \\
\hline 8 & Glial fibrillary acidic protein (fragment) & Q866S9 & 5,2 & 48000 & 4,7 & 44342 & 11 & 24 & 2 \\
\hline 8 & Glial fibrillary acidic protein (fragment) & P03995 & 5,4 & 50000 & 5,0 & 31776 & 9 & 21 & 2 \\
\hline 9 & Testis cDNA, similar to human desmin & Q4R7K6 & 5,1 & 24000 & 4,7 & 24070 & 12 & 38 & 2 \\
\hline 10 & Vimentin & P31000 & 5,1 & 54000 & 4,5 & 23085 & 15 & 22 & 2 \\
\hline 10 & Vimentin & P31000 & 5,1 & 54000 & 5,1 & 22777 & 14 & 23 & 2 \\
\hline 10 & Vimentin & P31000 & 5,1 & 54000 & 4,6 & 21138 & 17 & 28 & 2 \\
\hline 10 & Vimentin & P31000 & 5,1 & 54000 & 4,6 & 20825 & 13 & 22 & 2 \\
\hline 11 & Tropomyosin-1 & Q60527 & 4,6 & 33000 & 4,6 & 40365 & 16 & 51 & 3 \\
\hline 11 & Tropomyosin alpha isoform & Q923Z2 & 4,7 & 33000 & 4,6 & 36876 & 8 & 24 & 3 \\
\hline 11 & Tropomyosin isoform 8 of $\mathrm{P} 04692$ & P04692-8 & 4,8 & 29000 & 4,9 & 37590 & 7 & 24 & 3 \\
\hline 11 & Tropomyosin isoform 4 of $\mathrm{P} 04692$ & P04692-4 & 4,8 & 29000 & 5,4 & 42564 & 10 & 38 & 3 \\
\hline 12 & Alpha-tropomyosin 3 & Q63607 & 4,7 & 33000 & 9,3 & 49605 & 11 & 29 & 2 \\
\hline 13 & Tropomyosin 3, gamma & Q8K0Z5 & 4,7 & 33000 & 4,8 & 27739 & 10 & 32 & 3 \\
\hline 14 & Tropomyosin isoform 6 & Q63610 & 4,8 & 29000 & 4,7 & 32061 & 14 & 46 & 3 \\
\hline 14 & Tropomyosin isoform 6 & Q63610 & 4,8 & 29000 & 4,8 & 32157 & 8 & 36 & 3 \\
\hline 15 & Tropomyosin alpha- 4 chain & P09495 & 4,7 & 28000 & 4,6 & 32471 & 15 & 43 & 3 \\
\hline 16 & Lamin-A & P48679 & 6,5 & 74000 & 5,2 & 42694 & 13 & 21 & 3 \\
\hline 16 & LMNA protein & Q8N519 & 6 & 53000 & 5,5 & 38527 & 10 & 19 & 3 \\
\hline 17 & Lamin-B2 & P21619 & 5,4 & 67000 & 5,6 & 59799 & 12 & 18 & 3 \\
\hline 18 & Transgelin. & P31232 & 8,9 & 22000 & 9,6 & 24360 & 7 & 40 & 2 \\
\hline 19 & Myosin light polypeptide 6 & Q64119 & 4,5 & 17000 & 4,3 & 19735 & 5 & 39 & 1 \\
\hline \multicolumn{10}{|c|}{ Associated with cell growth, development, and differentiation } \\
\hline 20 & Neuromodulin & Q6S9D9 & 4,7 & 25000 & 4,5 & 23714 & 9 & 22 & 3 \\
\hline 21 & Pigment epithelium-derived factor & P97298 & 6,5 & 44000 & 5,5 & 52395 & 8 & 20 & 1 \\
\hline 21 & Pigment epithelium-derived factor & P97298 & 6,5 & 44000 & 5,4 & 51521 & 6 & 14 & 1 \\
\hline 22 & Protein Wnt-5b & Q9H1J7 & 8,8 & 39000 & 5,7 & 23432 & 8 & 20 & 1 \\
\hline 23 & DIXDC1 protein (fragment) & Q8IVY4 & 6 & 41000 & 6,0 & 33333 & 9 & 24 & 3 \\
\hline 24 & AHNAK 1 (fragment) & Q38PG1 & 5,2 & 59000 & 5,2 & 38623 & 14 & 22 & 3 \\
\hline 25 & SPARC & Q6GSZ4 & 4,8 & 34000 & 4,7 & 44342 & 15 & 38 & 1 \\
\hline 26 & Leukemia inhibitory factor & P17777 & 9 & 20000 & 6,0 & 23432 & 4 & 30 & 1 \\
\hline \multicolumn{10}{|c|}{ Chaperones } \\
\hline 27 & Calreticulin & P18418 & 4,3 & 46000 & 4,3 & 53430 & 14 & 38 & 1 \\
\hline 28 & Heat shock protein 8 & Q4FZY7 & 5,4 & 71000 & 5,4 & 69248 & 26 & 51 & 3 \\
\hline
\end{tabular}


TABLE 2: Continued.

\begin{tabular}{|c|c|c|c|c|c|c|c|c|c|}
\hline Protein number & Protein name & UniProt ID & $\mathrm{pI}(\mathrm{T})$ & $\mathrm{MW}(\mathrm{T})$ & $\mathrm{pI}(\mathrm{E})$ & MW (E) & n.pep & $\% \operatorname{Cov}$ & Secretion \\
\hline 29 & $78 \mathrm{kDa}$ glucose-regulated protein & P06761 & 5 & 70000 & 5,0 & 68834 & 13 & 25 & 1 \\
\hline 30 & Serpinh1 protein & Q5RJR9 & 8,9 & 47000 & 9,3 & 49605 & 17 & 40 & 1 \\
\hline 31 & Calumenin & $\mathrm{O} 35783$ & 4,4 & 35000 & 4,3 & 49231 & 5 & 24 & 1 \\
\hline \multicolumn{10}{|c|}{ Metabolism } \\
\hline 32 & Phosphoglycerate kinase 1 & P16617 & 7,5 & 44000 & 8,0 & 46687 & 14 & 41 & 3 \\
\hline 33 & Enolase 1, alpha & Q5EB49 & 6,2 & 47000 & 6,0 & 53471 & 10 & 28 & 2 \\
\hline 34 & Fructose-bisphosphate aldolase A & P05065 & 8,4 & 39000 & 8,8 & 42888 & 12 & 29 & 3 \\
\hline 35 & Isoform M2 of Pyruvate kinase & P11980-2 & 7,4 & 58000 & 7,4 & 61394 & 23 & 52 & 3 \\
\hline 36 & Carbonyl reductase [NADPH] 1 & P47727 & 8,2 & 30000 & 6,7 & 27573 & 9 & 32 & 2 \\
\hline 37 & Adult male cDNA, similar to GTPasa & Q3UH20 & 7 & 43000 & 4,6 & 28837 & 12 & 20 & 3 \\
\hline \multicolumn{10}{|c|}{ Transport proteins } \\
\hline 38 & Transcobalamin-2 & Q9R0D6 & 7,8 & 46000 & 8,0 & 46687 & 11 & 25 & 1 \\
\hline 39 & Ferritin light chain 1 & Q6P7T1 & 6 & 21000 & 6,0 & 20981 & 7 & 53 & 3 \\
\hline 40 & Syntaxin-binding protein 3 & Q60770 & 8,3 & 68000 & 6,0 & 64613 & 16 & 24 & 3 \\
\hline 41 & Synaptotagmin 5 & Q56A28 & 9,4 & 43000 & 9,1 & 43084 & 8 & 20 & 1 \\
\hline 42 & AP- 4 complex subunit sigma-1 & Q9Y587 & 5,1 & 17000 & 3,7 & 18044 & 4 & 36 & 3 \\
\hline
\end{tabular}

\begin{tabular}{lccccccccc}
43 & \multicolumn{9}{c}{ GTPase-related proteins } \\
44 & Ras-related protein Rab-14 & Q91V41 & 5,9 & 24000 & 6,0 & 23432 & 7 & 39 & 3 \\
45 & RAB15, member RAS oncogene family & Q504L6 & 5,4 & 24000 & 4,4 & 19298 & 6 & 29 & 1 \\
\hline
\end{tabular}

\begin{tabular}{cccccccccc}
\multicolumn{1}{c}{ Immune response } \\
46 & MHC class I antigen & Q9MXM3 & 5,5 & 40000 & 5,9 & 30475 & 10 & 38 & 1 \\
47 & Lysozyme C & P61626 & 9,3 & 15000 & 8,5 & 18234 & 7 & 39 & 1 \\
48 & Cutaneous T-cell lymphoma-associated & Q8IX95 & 4,9 & 18000 & 6,0 & 38747 & 5 & 48 & 2 \\
49 & antigen & & & & & & \\
40 & Recombination-activating gene 1 & Q5W9V9 & 6,4 & 38000 & 4,6 & 37876 & 11 & 41 & 2 \\
51 & Islet cell autoantigen 1-like protein & Q6RUG5 & 5,2 & 49000 & 5,4 & 59799 & 8 & 24 & 3 \\
50 & APG16 autophagy 16-like & Q3TDQ5 & 5,9 & 66000 & 7,0 & 61394 & 8 & 18 & 3 \\
\hline
\end{tabular}

\begin{tabular}{|c|c|c|c|c|c|c|c|c|c|}
\hline \multicolumn{10}{|c|}{ Extracellular matrix and related proteins } \\
\hline 52 & Alpha-1 type I procollagen (fragment) & Q60785 & 5,7 & 35000 & 5,2 & 34660 & 11 & 42 & 1 \\
\hline 53 & Collal protein (fragment) & Q99LL6 & 5,9 & 59000 & 5,7 & 51246 & 7 & 20 & 1 \\
\hline 53 & Collal protein (fragment) & Q99LL6 & 5,9 & 59000 & 5,6 & 51626 & 12 & 30 & 1 \\
\hline 54 & Colla2 protein (fragment) & Q91VL4 & 7,1 & 57000 & 6,0 & 32431 & 7 & 15 & 1 \\
\hline 55 & procollagen, type III, alpha 1 & Q8BJU6 & 5,9 & 36000 & 5,3 & 33602 & 10 & 36 & 1 \\
\hline 56 & Collagen alpha-1 (III) chain & P13941 & 9,4 & 94000 & 7,6 & 174792 & 15 & 20 & 1 \\
\hline 57 & Collagen alpha 1 (V) (fragment) & O70603 & 4,8 & 22000 & 4,4 & 36028 & 7 & 52 & 1 \\
\hline 58 & Glypican 1 variant (fragment) & Q59GI7 & 6,5 & 36000 & 5,6 & 33085 & 6 & 22 & 1 \\
\hline 59 & Perlecan & Q05793 & 5,9 & 17800 & 6,2 & 23432 & 8 & 11 & 1 \\
\hline \multicolumn{10}{|c|}{ Retinol-related proteins } \\
\hline 60 & $\begin{array}{l}\text { Dehydrogenase/reductase SDR family } \\
\text { member }\end{array}$ & Q9BTZ2 & 7,7 & 28000 & 8,0 & 36876 & 4 & 11 & 3 \\
\hline 61 & Epididymal retinoic acid-binding protein & P06911 & 5,5 & 18000 & 5,3 & 23432 & 4 & 37 & 1 \\
\hline
\end{tabular}

Secretion is indicated with (1) if the protein had a predicted signal peptide, (2) if it had a score $>0,5$ in neural network and therefore are nonclassically secreted, or (3) if they are not predicted as secreted. Proteins are listed with the accession number of Swiss-Prot and grouped in clusters of families and functions. (T) MW and pI as determined by UniProt database; (E) experimentally found in our $2 \mathrm{D}$ gels. \% Cov: \% of the sequence coverage by peptide mass fingerprinting using Aldente software, n.pep.: number of peptide masses matched. 


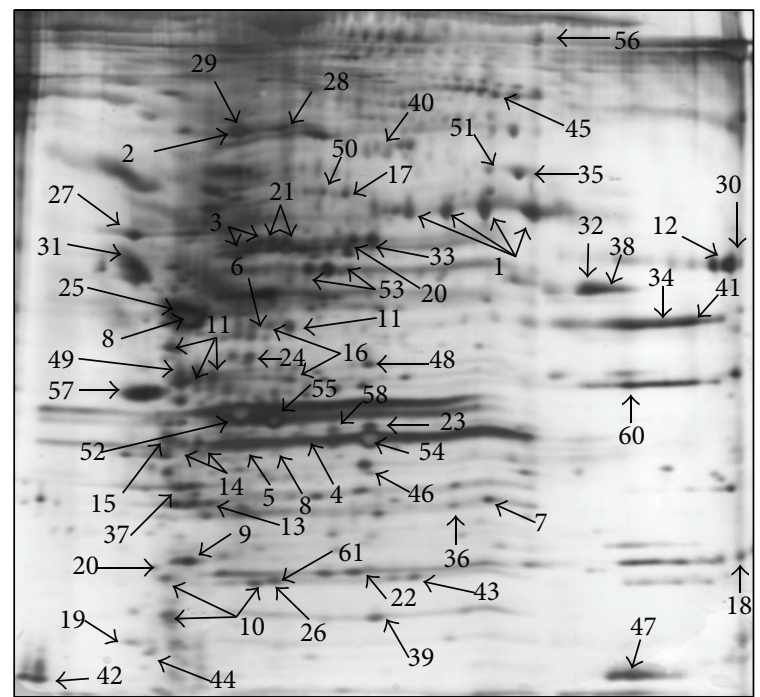

(a)

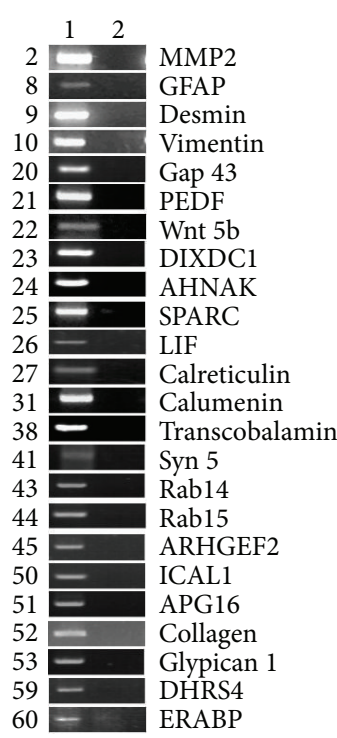

(b)

Figure 1: Secretome of PaSCs-ABCG2(+). (a) Silver-stained 2D gels of proteins secreted into the media by PaSCs-ABCG2(+). (b) Gene expression of some genes by RT-PCR, corresponding to the proteins identified by proteomic analysis. Total RNA from PaSCs-ABCG2(+) (lane 1), negative control (lane 2).

be secreted, either via classical pathways, that is, endoplasmic reticulum/Golgi-dependent pathway (contained a signal peptide), or via nonclassical pathways (without signal peptide, but with a Neural Network score superior than 0.5) (Table 2). The rest of the proteins were not predicted to be secreted by the current available software. However, we cannot exclude secretion via undescribed nonclassical mechanisms. Overall, we detected 37 soluble factors with a described secretion signature. Further analyses were performed by RT-PCR on a subset of candidate proteins in order to confirm the results obtained from proteomic analysis. For instance, we verified the identity of those factors relevant for their biological function and the ones that were identified as a gender different from rats. The proteins confirmed that the RNA levels are included in Figure 1(b). Among these proteins were some novel findings, including serpin family member PEDF, Wnt5b, and LIF. They were reported for the first time to be secreted by PaSC-ABCG2(+).

3.3. Secretome Network Analysis. To gain further insight into the potential functions of PaSC-ABCG2(+) secretome, we conducted proteomic data mining by Ingenuity Pathway Analysis 3.0 (Ingenuity Systems). Proteins identified in the secretome were submitted as "focus proteins" and were mapped onto the Ingenuity Pathways Knowledge Base, which is a database containing important curated information of interactions between genes, proteins, and other biological molecules. Our analysis rendered three main networks (Figures 2(a), 2(b), and 2(c)). Abbreviations of all the proteins used by the software are summarised in Table 3 . The scores for all of the mapped networks were higher than 19 , indicating that the networks selected were not due to random chance alone. These networks were associated with the following functions: cellular assembly and organisation (network 1, score 27, 15 focused proteins), tissue development (network 2, score 27, 15 focus proteins), cell-to-cell signalling and interaction, and cellular growth and proliferation (network 3, score 22, 13 focus proteins). The first scored network (Figure 2(a)) highlighted TGF $\beta 1$ as a nonfocused protein (included by the software to complete the network), which is located as a central node of the network.

The second and third scored networks obtained from Ingenuity Pathways are represented in Figures 2(b) and 2(c). Most of the factors implicated in development and differentiation processes are located in the extracellular compartment, with capacity to interact with the neighbouring cells. These soluble factors include SPARC, MMP2, PEDF, Wnt5b and collagens in the second network (Figure 2(b)), and LIF, which is also a secreted factor clustered in the third network (Figure $2(\mathrm{c})$ ).

3.4. TGF $\beta 1$ Detection and Their Role in Cell Proliferation. TGF $\beta 1$ was a central protein highlighted in our secretome network (Figure 2(a)), and thus we decided to explore if this factor was present in our conditioned media. ELISA immunoassay of the conditioned media revealed that PaSCABCG2(+) secreted active TGF $\beta 1$ at the concentration of $48.95 \pm 5.18 \mathrm{pg} / \mathrm{mL}(n=10)$ (Figure 3(a)). Our results were in agreement with previous reports [22,23].

TGF $\beta 1$ has a potent growth inhibitor capacity described in most cell types $[24,25]$ and is also capable of inducing Epithelial to Mesenchymal Transitions (EMT) in a variety of epithelial cells [26]. After detecting TGF $\beta 1$ in the PaSCABCG2(+) conditioned media, we wanted to explore if this molecule had antiproliferative effects in ductal cell line (ARIP cells). In order to conduct these experiments, first we explore 
TABLE 3: Abbreviations of all the proteins (focus and nonfocus) that appear in the three networks proposed by Ingenuity Pathways.

\begin{tabular}{|c|c|c|c|c|c|}
\hline Name & Description & GenBank & Networks & Location & Family \\
\hline AHNAK & $\begin{array}{l}\text { AHNAK nucleoprotein } \\
\text { (desmoyokin) }\end{array}$ & DQ203293 & 3 & Nucleus & Other \\
\hline AK2 & Adenylate kinase 2 & - & 3 & Cytoplasm & Kinase \\
\hline ALDOA & Aldolase A, fructose-bisphosphate & M12919 & 3 & Cytoplasm & Enzyme \\
\hline ANXA4 & Annexin A4 & - & 1 & Plasma membrane & Other \\
\hline ARHGEF2 & $\begin{array}{l}\text { rho/rac guanine nucleotide exchange } \\
\text { factor (GEF) } 2\end{array}$ & NM_001012079 & 1 & Cytoplasm & Other \\
\hline BAT1 & HLA-B associated transcript 1 & - & 1 & Nucleus & Enzyme \\
\hline CALR & Calreticulin & D78308 & 3 & Nucleus & $\begin{array}{l}\text { Transcription } \\
\text { regulator }\end{array}$ \\
\hline CALU & Calumenin & AJ001929 & 1 & Unknown & Other \\
\hline CBR1 & Carbonyl reductase 1 & X84349 & 3 & Cytoplasm & Enzyme \\
\hline CD300D & Cd300D antigen & - & 3 & Plasma membrane & $\begin{array}{l}\text { Transmembrane } \\
\text { receptor }\end{array}$ \\
\hline CIAA1 & CIA autoantibody QTL 1 & - & 2 & Unknown & Other \\
\hline CIAA2 & CIA autoantibody QTL 2 & - & 2 & Unknown & Other \\
\hline CIB2 & $\begin{array}{l}\text { Calcium and integrin binding family } \\
\text { member } 2\end{array}$ & - & 3 & Unknown & Kinase \\
\hline CNN3 & Calponin 3 , acidic & - & 1 & Cytoplasm & Other \\
\hline COL10A1 & Collagen, type $\mathrm{X}$, alpha 1 & - & 2 & Extracellular space & Other \\
\hline COL11A2 & Collagen, type XI, alpha 2 & - & 2 & Extracellular space & Other \\
\hline COL14A1 & Collagen, type XIV, alpha 1 (undulin) & - & 2 & Extracellular space & Other \\
\hline COL1A1 & Collagen, type I, alpha 1 & XM_213440 & 2 & Extracellular space & Other \\
\hline COL1A2 & Collagen, type I, alpha 2 & AF121217 & 2 & Extracellular space & Other \\
\hline COL2A1 & Collagen, type II, alpha 1 & - & 2 & Extracellular space & Other \\
\hline COL3A1 & Collagen, type III, alpha 1 & BC087039 & 2 & Extracellular space & Other \\
\hline COL5A1 & Collagen, type V, alpha 1 & AJ005394 & 1 & Extracellular space & Other \\
\hline COL5A3 & Collagen, type V, alpha 3 & - & 2 & Extracellular space & Other \\
\hline CTSB & Cathepsin B & NM_022597 & 3 & Cytoplasm & Peptidase \\
\hline DDR1 & $\begin{array}{l}\text { Discoidin domain receptor family, } \\
\text { member } 1\end{array}$ & - & 2 & Plasma membrane & Kinase \\
\hline DDR2 & $\begin{array}{l}\text { Discoidin domain receptor family, } \\
\text { member } 2\end{array}$ & - & 2 & Plasma membrane & Kinase \\
\hline DDX18 & $\begin{array}{l}\text { DEAD (Asp-Glu-Ala-Asp) box } \\
\text { polypeptide } 18\end{array}$ & - & 1 & Nucleus & Enzyme \\
\hline DES & Desmin & NM_022531 & 1 & Unknown & Other \\
\hline DHRS4 & $\begin{array}{l}\text { Dehydrogenase/reductase (SDR } \\
\text { family) member } 4\end{array}$ & NM_153315 & 1 & Unknown & Enzyme \\
\hline DIXDC1 & DIX domain containing 1 & NM_001037654 & 1 & Unknown & Other \\
\hline ELF3 & E74-like factor 3 & - & 3 & Nucleus & $\begin{array}{l}\text { Transcription } \\
\text { regulator }\end{array}$ \\
\hline ENO1 & Enolase 1, (alpha) & BC090069 & 1 & Cytoplasm & $\begin{array}{l}\text { Transcription } \\
\text { regulator }\end{array}$ \\
\hline $\mathrm{F} 2$ & Coagulation factor II (thrombin) & - & 3 & Extracellular space & Peptidase \\
\hline FCGR1B & $\begin{array}{l}\text { Fc fragment of IgG, high affinity Ib, } \\
\text { receptor (CD64) }\end{array}$ & - & 3 & Plasma membrane & $\begin{array}{l}\text { Transmembrane } \\
\text { receptor }\end{array}$ \\
\hline FCGR1C & $\begin{array}{l}\text { Fc fragment of IgG, high affinity Ic, } \\
\text { receptor (CD64) }\end{array}$ & - & 3 & Plasma membrane & $\begin{array}{l}\text { Transmembrane } \\
\text { receptor }\end{array}$ \\
\hline FFAR2 & Free fatty acid receptor 2 & - & 3 & Plasma membrane & $\begin{array}{l}\text { G-protein coupled } \\
\text { receptor }\end{array}$ \\
\hline FOS & v-fos FBJ murine oncogene homolog & - & 1 & Nucleus & $\begin{array}{l}\text { Transcription } \\
\text { regulator }\end{array}$ \\
\hline
\end{tabular}


TABle 3: Continued.

\begin{tabular}{|c|c|c|c|c|c|}
\hline Name & Description & GenBank & Networks & Location & Family \\
\hline FTL & Ferritin, light polypeptide & BC061525 & 3 & Cytoplasm & Other \\
\hline GAP43 & Growth associated protein 43 & NM_017195 & 2 & Plasma membrane & Other \\
\hline GFAP & Glial fibrillary acidic protein & U03700 & 3 & Cytoplasm & Other \\
\hline GSTA4 & Glutathione s-transferase a4 & - & 3 & Cytoplasm & Enzyme \\
\hline HSPA5 & Heat shock $70 \mathrm{kda}$ protein 5 & M14050 & 1 & Cytoplasm & Other \\
\hline HSPA8 & Heat shock $70 \mathrm{kda}$ protein 8 & ВС098914 & 2 & Cytoplasm & Enzyme \\
\hline HSPH1 & Heat shock $105 \mathrm{kda} / 110 \mathrm{kda}$ protein 1 & - & 2 & Cytoplasm & Other \\
\hline IL6 & Interleukin 6 (interferon, $\beta 2$ ) & - & 3 & Extracellular space & Cytokine \\
\hline IL15 & Interleukin 15 & - & 1 & Extracellular space & Cytokine \\
\hline IL1F6 & $\begin{array}{c}\text { Interleukin } 1 \text { family, member } 6 \\
\text { (epsilon) }\end{array}$ & - & 3 & Extracellular space & Cytokine \\
\hline IL1F9 & Interleukin 1 family, member 9 & - & 3 & Extracellular space & Cytokine \\
\hline KCTD13 & $\begin{array}{c}\text { Potassium channel domain } \\
\text { containing } 13\end{array}$ & - & 3 & Cytoplasm & Ion channel \\
\hline KNG1 & Kininogen 1 & - & 3 & Extracellular space & Other \\
\hline LARGE & Like-glycosyltransferase & - & 3 & Cytoplasm & Enzyme \\
\hline LIF & Leukemia inhibitory factor & NM_022196 & 3 & Extracellular space & Cytokine \\
\hline LMNA & Lamin A/C & NM_001002016 & 2 & Nucleus & Other \\
\hline MAPK8 & Mitogen-activated protein kinase 8 & - & 1 & Cytoplasm & Kinase \\
\hline MMP2 & Matrix metallopeptidase 2 & X71466 & 2 & Extracellular Space & Peptidase \\
\hline MYC & v-myc viral oncogene homolog & - & 1 & Nucleus & $\begin{array}{l}\text { Transcription } \\
\text { regulator }\end{array}$ \\
\hline MYCN & $\mathrm{v}$-myc viral related oncogene & - & 3 & Nucleus & $\begin{array}{l}\text { Transcription } \\
\text { regulator }\end{array}$ \\
\hline MYL6 & Myosin, light polypeptide 6 & XM_001053789 & 3 & Cytoplasm & Other \\
\hline OMG & Oligodendrocyte myelin glycoprotein & - & 1 & Plasma membrane & $\begin{array}{l}\text { G-protein coupled } \\
\text { receptor }\end{array}$ \\
\hline P4HA1 & $\begin{array}{l}\text { Procollagen-proline alpha } \\
\text { polypeptide i }\end{array}$ & - & 2 & Cytoplasm & Enzyme \\
\hline P4HB & Procollagen-proline, $\beta$ polypeptide & - & 2 & Cytoplasm & Enzyme \\
\hline PCOLCE & $\begin{array}{c}\text { Procollagen c-endopeptidase } \\
\text { enhancer }\end{array}$ & U94710 & 2 & Extracellular space & Other \\
\hline PDLIM7 & PDZ and LIM domain 7 (enigma) & - & 1 & Cytoplasm & Other \\
\hline PGK1 & Phosphoglycerate kinase 1 & ВC063161 & 1 & Cytoplasm & Kinase \\
\hline PKIG & Protein kinase inhibitor gamma & - & 1 & Unknown & Other \\
\hline PKM2 & Pyruvate kinase, muscle & M24359 & 3 & Cytoplasm & Kinase \\
\hline PLS3 & Plastin 3 (t isoform) & - & 1 & Cytoplasm & Other \\
\hline PLXNB2 & Plexin $b 2$ & - & 2 & Plasma membrane & Other \\
\hline PPP1R15A & Protein phosphatase 1 , subunit $15 a$ & - & 2 & Cytoplasm & Other \\
\hline PRL & Prolactin & - & 1 & Extracellular space & Cytokine \\
\hline PSMD6 & $\begin{array}{c}\text { Proteasome 26S subunit, } \\
\text { non-ATPase, } 6\end{array}$ & NM_198730 & 1 & Cytoplasm & Other \\
\hline RAB14 & $\begin{array}{l}\text { RAB14, member RAS oncogene } \\
\text { family }\end{array}$ & NM_053589 & 2 & Cytoplasm & Enzyme \\
\hline RAG1 & Recombination activating gene 1 & XM_001079242 & 3 & Nucleus & Enzyme \\
\hline RPS18 & Ribosomal protein S18 & - & 1 & Cytoplasm & Other \\
\hline SERPINB8 & $\begin{array}{l}\text { Serpin peptidase inhibitor, clade B } \\
\text { member } 8\end{array}$ & - & 3 & Cytoplasm & Other \\
\hline SERPINE1 & $\begin{array}{c}\text { Serpin peptidase inhibitor, clade E } \\
\text { member } 1\end{array}$ & - & 2 & Extracellular space & Other \\
\hline SERPINF1 & $\begin{array}{l}\text { Serpin peptidase inhibitor, clade } \mathrm{F} \\
\text { (pigment epithelium derived factor) }\end{array}$ & BC078686 & 2 & Extracellular space & Other \\
\hline
\end{tabular}


TABle 3: Continued.

\begin{tabular}{|c|c|c|c|c|c|}
\hline Name & Description & GenBank & Networks & Location & Family \\
\hline SERPINH1 & $\begin{array}{l}\text { Serpin peptidase inhibitor, clade } \mathrm{H} \\
\text { (heat shock protein } 47 \text { ) }\end{array}$ & ВC086529 & 2 & Extracellular Space & Other \\
\hline SLC16A5 & $\begin{array}{l}\text { Solute carrier family } 16 \text {, member } 5 \\
\text { (monocarboxylic acid transporter } 6 \text { ) }\end{array}$ & - & 3 & Plasma membrane & Transporter \\
\hline SLCO1A2 & $\begin{array}{l}\text { Solute carrier organic anion } \\
\text { transporter family, member 1A2 }\end{array}$ & - & 3 & Plasma membrane & Transporter \\
\hline SMARCB1 & $\begin{array}{l}\text { SWI/SNF related, matrix associated, } \\
\text { subfamily } b \text {, member } 1\end{array}$ & - & 2 & Nucleus & Other \\
\hline SP1 & Spl transcription factor & - & 3 & Nucleus & $\begin{array}{l}\text { Transcription } \\
\text { regulator }\end{array}$ \\
\hline SPARC & $\begin{array}{l}\text { Secreted protein, acidic, cysteine-rich } \\
\text { (osteonectin) }\end{array}$ & ВС061777 & 2 & Extracellular space & Other \\
\hline STXBP3 & Syntaxin binding protein 3 & NM_053637 & 3 & Plasma membrane & Transporter \\
\hline SUMO2 & $\begin{array}{c}\text { SMT3 suppressor of mif two } 3 \\
\text { homolog } 2 \text { (yeast) }\end{array}$ & - & 1 & Unknown & Other \\
\hline TAGLN & Transgelin & NM_031549 & 3 & Cytoplasm & Other \\
\hline TCN2 & $\begin{array}{c}\text { Transcobalamin II, macrocytic } \\
\text { anemia }\end{array}$ & AF054810 & 2 & Extracellular space & Transporter \\
\hline TGFB1 & Transforming growth factor, $\beta 1$ & - & 1 & Extracellular space & Growth factor \\
\hline THBS2 & Thrombospondin 2 & - & 2 & Extracellular space & Other \\
\hline TNF & $\begin{array}{l}\text { Tumor necrosis factor (TNF } \\
\text { superfamily, member 2) }\end{array}$ & - & 3 & Extracellular space & Cytokine \\
\hline TOR2A & Torsin family 2 , member A & - & 1 & Extracellular space & Other \\
\hline TP53 & Tumor protein p53 & - & 2 & Nucleus & $\begin{array}{l}\text { Transcription } \\
\text { regulator }\end{array}$ \\
\hline TPM1 & Tropomyosin 1 (alpha) & M60667 & 1 & Cytoplasm & Other \\
\hline TPM2 & Tropomyosin $2(\beta)$ & ВC090009 & 1 & Cytoplasm & Other \\
\hline TPM3 & Tropomyosin 3 & NM_057208 & 1 & Cytoplasm & Other \\
\hline TPM4 & Tropomyosin 4 & J02780 & 1 & Cytoplasm & Other \\
\hline TSPAN7 & Tetraspanin 7 & - & 1 & Plasma membrane & Other \\
\hline UBR2 & $\begin{array}{l}\text { Ubiquitin protein ligase E3 } \\
\text { component n-recognin } 2\end{array}$ & - & 3 & Unknown & Enzyme \\
\hline UPP1 & Uridine phosphorylase 1 & - & 2 & Cytoplasm & Enzyme \\
\hline USP15 & Ubiquitin specific peptidase 15 & AF106657 & & Cytoplasm & Peptidase \\
\hline VIM & Vimentin & X62952 & 2 & Cytoplasm & Other \\
\hline WNT5B & $\begin{array}{l}\text { Wingless-type MMTV integration } \\
\text { site family, member 5B }\end{array}$ & AF481944 & 2 & Extracellular space & Other \\
\hline YY2 & YY2 transcription factor & - & 1 & Unknown & Other \\
\hline ZBTB7B & $\begin{array}{l}\text { Zinc finger and BTB domain } \\
\text { containing 7B }\end{array}$ & - & 2 & Nucleus & $\begin{array}{l}\text { Transcription } \\
\text { regulator }\end{array}$ \\
\hline ZFP161 & $\begin{array}{l}\text { Zinc finger protein } 161 \text { homolog } \\
\text { (mouse) }\end{array}$ & - & 1 & Nucleus & Other \\
\hline
\end{tabular}

to see whether this cellular model has the capacity to respond to the TFG $\beta 1$ signal. The analysis of TGF $\beta$ receptors (type I, type II, and type III) in ARIP cells showed that expression of these receptors when cells was cultured with basal medium or with PaSC-ABCG2(+) conditioned medium (Figure 3(b)).

3.5. PaSC-ABCG2(+) Conditioned Media Inhibits Ductal Cell Proliferation without Altering Viability. In order to evaluate the effects of the conditioned medium in ARIP cells, we treated them during 24 hours and analysed the proliferation ratio by BrdU and their viability by MTT. The results showed that the rate of proliferation of ARIP cells treated with PaSC ABCG2(+) conditioned media was significantly reduced $(40.3 \% \pm 0.07$ relative to basal media no conditioned $P<0.01, n=4$, Figure 4(a)). In order to test the specificity of conditioned media, we cultured ARIP cells with conditioned media collected from other cell lines, endocrine $\alpha \mathrm{TC}$ and ductal mPAC, and we found that proliferation rate was not modified (data not shown). In addition, ARIP cell 


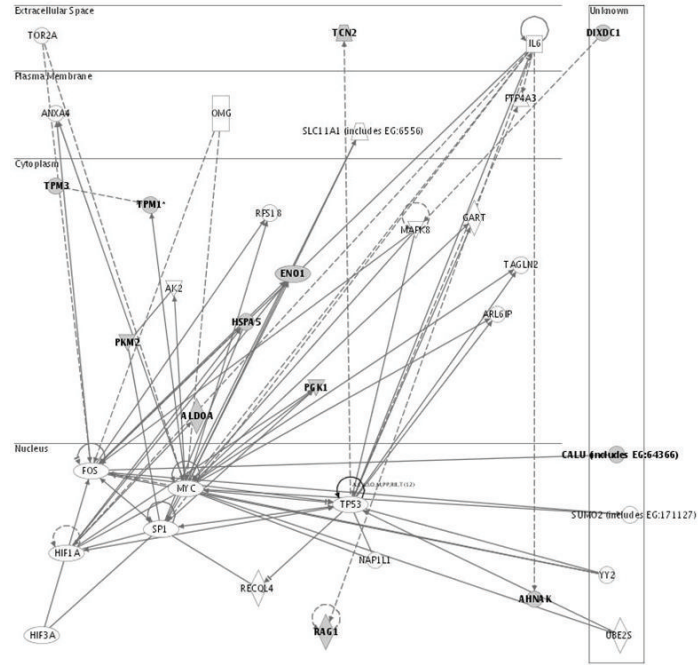

(a)

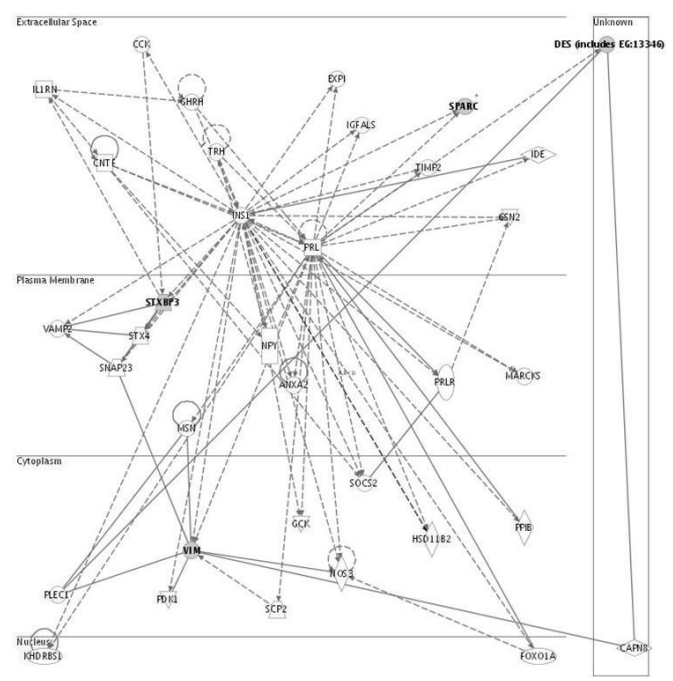

(b)

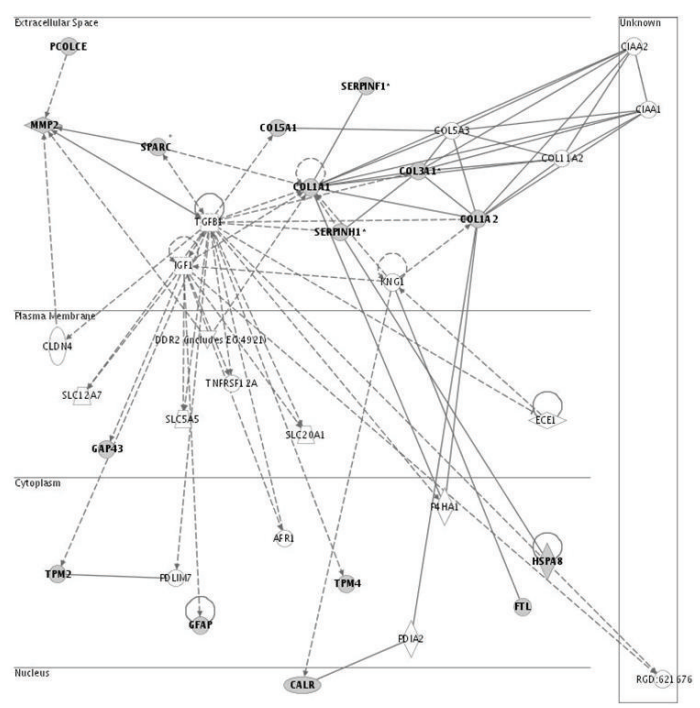

(c)

FIGURE 2: Ingenuity Pathways networks. These networks have resulted from submitting proteins identified in the secretome to the Ingenuity Pathways software. Proteins are classified in bold as focus proteins (which are obtained from our secretome results) or not in bold as nonfocus (which have been included by the software to complete the network). (a) The first network highlights TGF $\beta 1$ as a "nonfocus" protein. (b) The second network includes novel proteins in the secretome of PaSC such as PEDF (SerpinF1) and Wnt5b, which have interactions with other soluble proteins in the extracellular space. (c) The third-scored network identifies LIF in the extracellular space. Legend of the node shapes to identify the type of protein: rhombus: enzyme, square: growth factor, inverted triangle: kinase, circle: other, rectangle: ion channel, oval: transcription regulator.

viability was not affected by PaSC-ABCG2(+) conditioned media (MTT test, data not shown). The conditioned media also significantly reduced proliferation in other cell lines used as controls: AR42J and MIN6 (data not shown). The results indicated that specific soluble factors secreted by these cells had effects on ARIP proliferation without altering cell viability. In order to check if TGF $\beta 1$ was implicated in the antiproliferative effects of PaSC-ABCG2(+) secretome on ARIP cells, we blocked TGF $\beta 1$ from the conditioned media with a pan TGF $\beta$ antibody capable of neutralising its effects (Figure 3(c)). Adding pan-neutralising antibody to the conditioned media returned the rate of proliferation to the basal level. As a positive control, we added exogenous TGF $\beta 1(10 \mathrm{ng} / \mathrm{mL})$ to the basal media, which significantly reduced the rate of proliferation $(P<0.05)$, mimicking the effects of the stellate conditioned media. Exogenous TGF $\beta 1$ can also be blocked by pan TGF $\beta$ antibody, which returned the rate of proliferation to basal levels. Nonimmune IgG at $20 \mu \mathrm{g} / \mathrm{mL}$ was used as control of exogenous antibody and its addition caused no modifications on the proliferation rate. Moreover, none of these treatments caused effects on cell viability, evaluated by MTT test (data not shown). These experiments confirmed the implication of TGF $\beta 1$ secreted by stellate cells in the inhibition of the proliferation observed. 


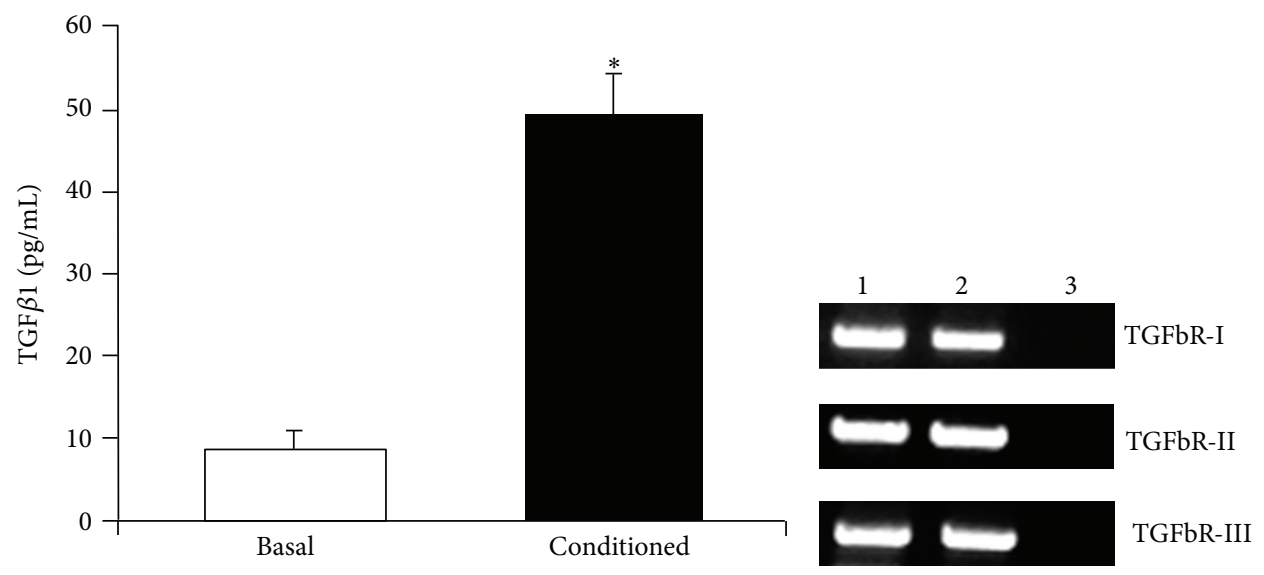

(a)

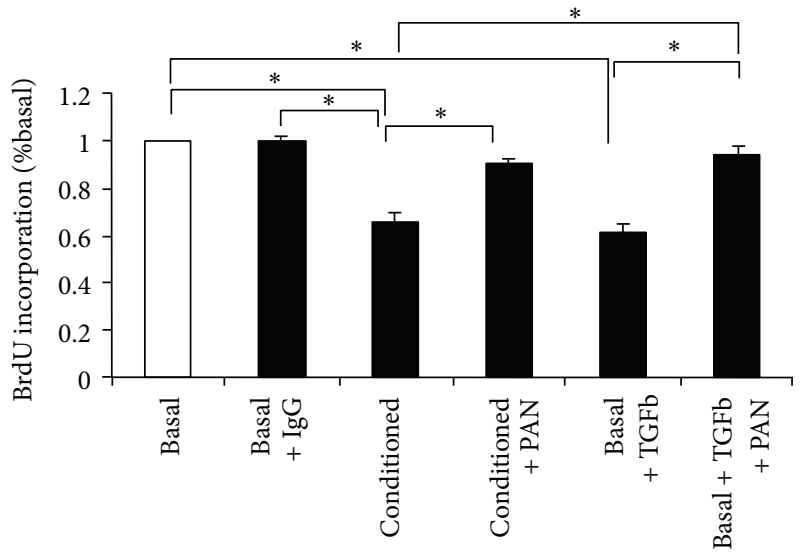

(c) (b)

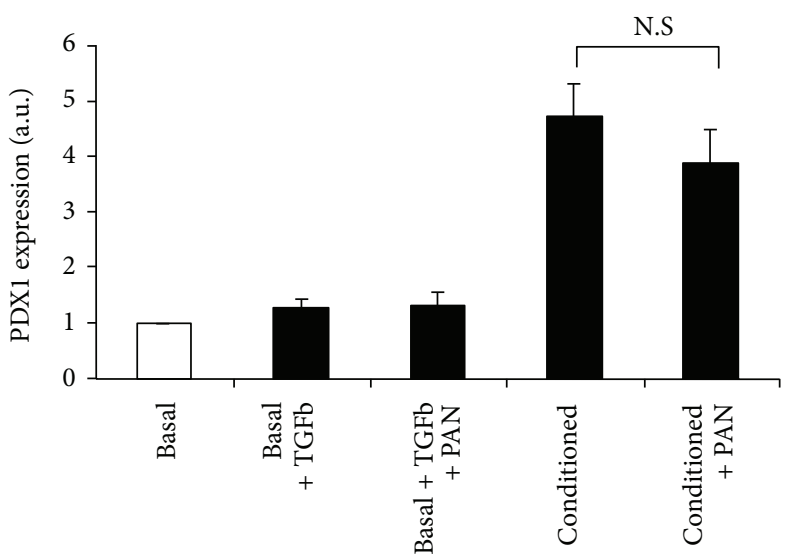

(d)

FIgURE 3: PaSCs-ABCG2(+) secrete TGF $\beta 1$, which causes the inhibition of proliferation but has no effect on PDX1 increase. (a) Quantification of active TGF $\beta 1$ in supernatant of PaSC cultured (conditioned media) for 24 hours. Active TGF $\beta 1$ was measured directly by ELISA, compared to TGF $\beta 1$ in the basal media $(n=8)$. (b) Expression of TGF $\beta$ receptors in ARIP cells detected by RT-PCR. Lanes: 1-basal media, 2 -conditioned media, 3-(-)RT. (c) Proliferation rate of ARIP cells (BrdU assay) after different stimulations: basal media, basal media plus nonimmune IgG $20 \mu \mathrm{g} / \mathrm{mL}$, conditioned media, conditioned media plus Pan TGF $\beta 20 \mu \mathrm{g} / \mathrm{mL}$, basal media plus TGF $\beta 110 \mathrm{ng} / \mathrm{mL}$, or basal media plus pan TGF $\beta$ and TGF $\beta 1$. Results are expressed as percentage of control values (basal media) and are representative of 3 separate experiments. The neutralising antibody can revert the inhibition of proliferation in ARIP cells treated with conditioned media. ${ }^{*}$ indicate statistical significance with $P<0.05$. (d) PDX1 expression of ARIP cells treated with basal media, conditioned media, conditioned media plus pan TGF $\beta 20 \mu \mathrm{g} / \mathrm{mL}$, basal media plus TGF $\beta 110 \mathrm{ng} / \mathrm{mL}$, or basal media plus pan TGF $\beta$ and TGF $\beta 1$. Results are expressed as fold increase of control values (basal media) and are representative of 6 independent experiments. NS indicates no statistical significance.

3.6. PaSC-ABCG2(+) Conditioned Media Modify CK19 and PDX1 Expression on Ductal Cell Line. Given the association between reducing cell proliferation and inducing differentiation, we decided to explore if PaSC-ABCG2(+) conditioned media produced changes in ARIP gene expression. The results showed that treatment with conditioned media during 72 hours caused a decrease of the ductal marker CK19, as detected by immunocytochemistry (Figure 4(b)). Quantitative real-time PCR indicated that conditioned media elicited a $0.48 \pm 0.05$-fold decrease in CK19 mRNA expression $(n=6, P<0.05$, Figure 4(c)). These results indicate that PaSC-ABCG2(+) conditioned media are able to induce changes in transcription of endogenous ARIP gene CK19.

One of the most critical genes involved in endocrine differentiation and beta cell phenotype maintenance is the transcription factor PDX1. In order to check if PaSCABCG2(+) conditioned media was able to modify PDX1 expression in this cellular model, first we evaluated the basal level of this transcription factor both at the protein and mRNA levels. We observed an increase of PDX1 when we treated them with PaSC-ABCG2(+) conditioned media (Figure 4(b)). Quantitative real-time PCR indicated that conditioned media treatment increased 5.38-fold \pm 0.7 PDX1 mRNA basal expression ( $n=6, P<0.05$, Figure $4(\mathrm{~d}))$. To determine if TGF $\beta 1$ had a role in increasing PDX1 mRNA levels in ARIP cells treated with PaSC-ABCG2(+) conditioned media, we used the pan-neutralising TGF $\beta$ in the conditioned media during 72 hours. The blocking antibody did not reduce significantly PDX1 induction caused by the conditioned media. Moreover, the addition of exogenous 


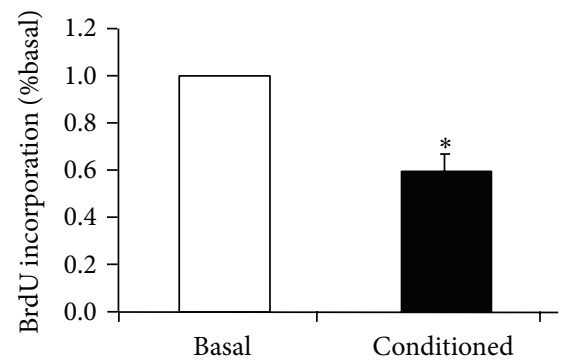

(a)
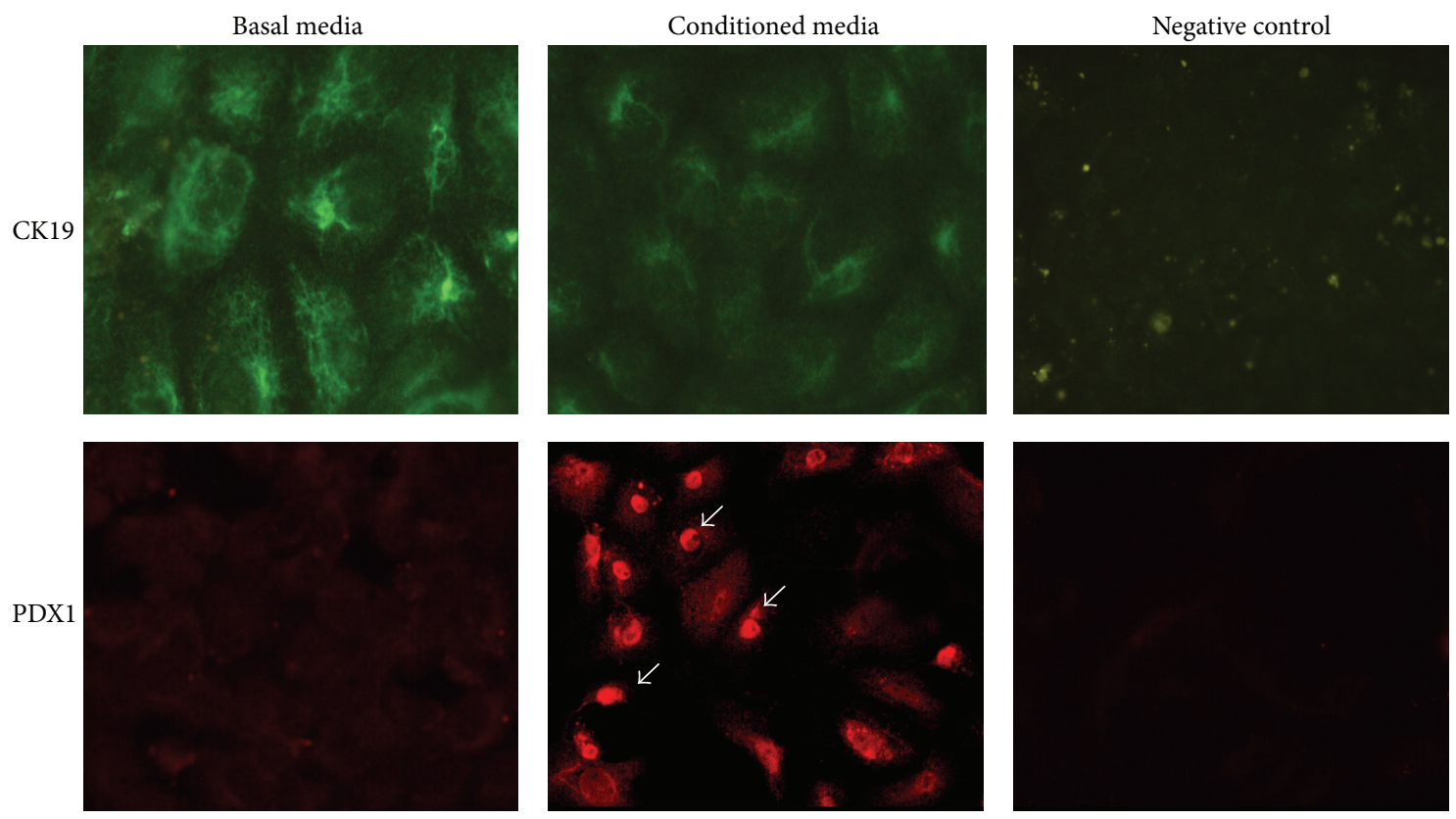

(b)

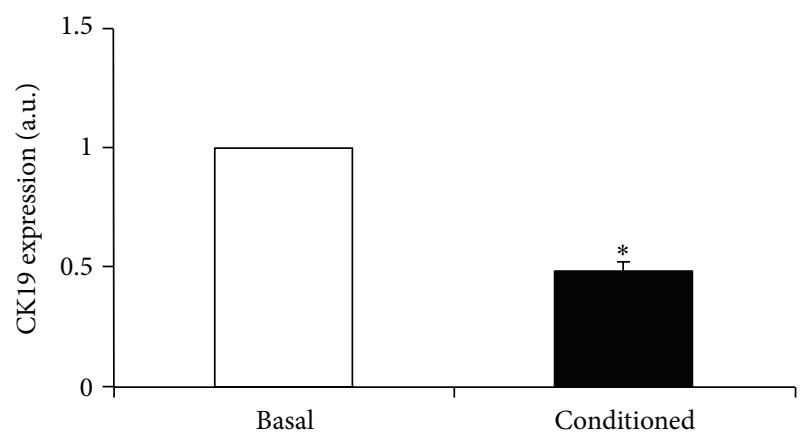

(c)

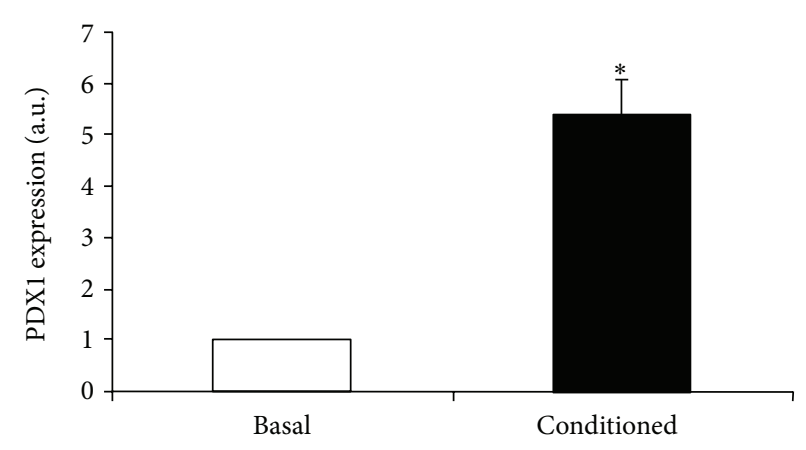

(d)

FIgure 4: Conditioned media from PaSCs-ABCG2(+) inhibit proliferation and modify gene expression in the ARIP cell line. (a) Proliferation rate of ARIP cells (BrdU assay) after 24 hours of treatment with basal media and conditioned media from PaSCs-ABCG2(+). Results are expressed as percentage of control values (basal media) and are representative of 4 independent experiments. ${ }^{*}$ indicate statistical significance with $P<0.05$. (b) Upper: immunocytochemistry of CK19 of ARIP cells treated for 72 hours with basal media (1) and conditioned media (2); only 2ari antibody (3). Magnification 20x. Lower: immunocytochemistry of PDX1 in ARIP cells treated for 72 hours basal media (1) and conditioned media (2); only 2ari antibody (3). Magnification 20x. ((c), (d)) CK19 and PDX1 expression by RT-PCR of ARIP cells treated for 72 hours with basal media (1) and conditioned media (2). mRNA levels present in cells treated with basal media were taken as reference and values were normalised to TBP mRNA levels. Bars indicate the SEM of three independent experiments performed in duplicate. ${ }^{*}$ indicate statistical significance with $P<0.05$. 
TGB $\beta 1(10 \mathrm{ng} / \mathrm{mL})$ to the control media for 72 hours did not induce PDX1 mRNA increased expression in ARIP cells (Figure 3(d)).These results indicate that TGF $\beta 1$ is not apparently involved in PDX1 increased expression of ARIPconditioned cells.

\section{Discussion}

Hepatic stellate cells (HpSC) are morphologically and functionally similar to PaSC. Thus, most of the previous studies on stellate cells in the liver predict similar effects of stellate cells in the pancreas [27]. These two cell types have been compared at a transcriptional level, exhibiting organ-specific variations of a common transcriptional phenotype [27]. In the liver, activated stellate cells are known to influence the growth and proliferation of other liver cell types, particularly hepatocytes through paracrine effects [28, 29]. HpSC-derived Keratinocyte Growth Factor is thought to enhance liver regeneration and/or hepatocyte survival in patients with chronic liver disease [30]. Other reports indicate that coculture of $\mathrm{HpSC}$ with hepatocytes can preserve some aspects of hepatocyte function [31]. Stellate cells' effects on inducing differentiation have been described previously in liver; for instance, coculture of $\mathrm{HpSC}$ with stem cells gives rise to hepatocytes [32]. At present, there is no report of similar effects in the pancreas. Adult stem cells in the pancreas have not been localised yet, but there is some evidence of their ductal residence (transdifferentiation of ductal cells or remanent stem cells of the duct) $[9,33,34]$. Multiple secreted factors from PaSC, which are located in periacinar and periductal, could have a key contribution in maintaining the ductal niche. Our results indicate that soluble factors secreted by PaSC-ABCG2(+) can inhibit ductal proliferation, as they are also able of inducing changes of gene expression in ductal cells (decrease of the endogenous gene CK19 and increase of the endocrine transcription factor PDX1).

The proteomic approach using Ingenuity Pathway Analysis 3.0 conducted in PaSC-ABCG2(+) conditioned media predicted three main networks. One of them shed light on TGF $\beta 1$ as a non-focused protein. This factor was not detected in $2 \mathrm{D}$ gels due to its low molecular weight $(12 \mathrm{kDa})$, which was too small for the resolution of the gels used in the analysis. Alternatively, TGF $\beta 1$ was detected by ELISA immunoassay. Using this technique, the results revealed that the levels of active TGF $\beta 1$ secreted to the conditioned media are similar to the ones described by other primary cultures of PaSCs $[22,35]$. It is known that the secretion of this protein is involved in the profibrogenic role of PaSC [36, 37]. Moreover, TGF $\beta 1$ induces the transformation of PaSC to myofibroblasts (as evidenced by increased $\alpha$ SMA expression) [38], and it also controls PaSC growth in an autocrine manner [39]. Our study demonstrated the capacity of the conditioned media obtained from PaSC culture to inhibit proliferation of the ARIP cell line and other cell lines, such as AR42J and MIN6, which were used as controls (data not shown). We identified TGF $\beta 1$ as the main inhibitor of the ARIP proliferation.

Because cell proliferation arrest is generally accompanied by an increase in cell differentiation, we analysed ARIP gene expression. Our results demonstrated changes in CK19 and PDX1 on ARIP-conditioned cells; therefore we tried to identify the molecule involved in PDX1-increased expression (which is a transcription factor involved in endocrine differentiation). Our first goal was to explore TGF $\beta 1$, based on previous studies that suggest a role of this factor in some differentiative processes [40, 41], including determination of pancreatic development $[42,43]$. However, we were unable to demonstrate the role of TGF $\beta 1$ on PDX1-enhanced expression in ARIP cells that have stopped proliferating, thus indicating that other soluble factors in the secretome had the capacity to modify PDX1 expression.

The second network also predicted by Ingenuity included serpinfl as a focus protein, also known as PEDF. This factor is involved in neurotrophic activity [44-46], and it has recently been involved in neural stem cell renewal as a niche signal [47]. It has been detected in the lung, the heart, and the liver, but its expression is nearly undetectable in the pancreas [48]. It was also interesting to find that this network also included a member of the Wingless family (Wnt5b). The WNT genes have been reported to play a pivotal role in embryonic development and oncogenesis; the isoform Wnt5b is expressed in the exocrine pancreas and upregulated in adipocyte differentiation $[49,50]$. SPARC (secreted protein acidic and rich in cysteine), an extracellular Ca-binding glycoprotein associated with the morphogenesis and remodelling of various tissues [51], and MMP2 (matrix metalloproteinase-2), important metalloproteinase that has the capacity to activate TGF $\beta 1$ [52], were also present as focus proteins in the second network. These proteins from our secretome (focus proteins) act as central nodes of the network, with described interactions between them.

Finally, the last network predicted highlights LIF, which has been described to induce astrocyte differentiation $[53,54]$ and is capable of generating insulin-producing beta cells from adult exocrine pancreatic cells in combination with EGF [55]. In this secretome we have found proteins associated with cell growth, development, and differentiation, which contain the novel findings PEDF, LIF, and Wnt5b. The data presented in our study provide a significant new proteinlevel insight into the secretome of active PaSCs-ABCG2(+). Some of these proteins may have potentially great influence on the physiology of the stellate cells themselves and/or of neighbouring cells. Further studies are required to determine a potential role of these factors in the PaSC-ABCG2(+) effects on ductal cells.

The type of secretion of the soluble factors analysed by SecretomeP indicated that $70 \%$ had a predicted signal peptide and $30 \%$ were secreted via nonclassical pathways which could involve membrane blebbing, exosomes, plasma membrane resident transporters, or lysosomal secretion [56]. Any of the secreted factors could be the potential candidates to exert the effects of the PaSC-ABCG2(+) conditioned media. The most abundant family of secreted factors is the extracellular matrix and related proteins, which coincides with the main function of PaSC (remodellation extracellular matrix remodeling and turnover). This family includes perlecan and collagens, components of the extracellular matrix which contribute to the creation of a microenvironment around PaSC acting as a pool of cytokines and growth factors. It should be noted that not all 
the proteins identified in our study are known to be secreted. The ones, which have no evidence of secretion, may originate from the minority of cells that die or are otherwise disrupted during the washing and harvesting steps of the procedure and also possibly secreted by unknown mechanisms. This is a common issue in proteomic analysis performed on secretome from primary cell cultures. Most of these proteins were derived from the intracellular compartment characteristic of the stellate phenotype and should be useful for their characterisation. Moreover, some of the proteins identified in the secretome were previously described to be secreted by hepatic stellate cells, such as SPARC, MMP2, cathepsin B, and collagens. The structural ones (calreticulin, $\alpha$-enolase, and vimentin) were also present in the study of hepatic stellate cells [56], and they were confirmed as the stellate phenotype in our study.

In summary, we have described new soluble factors secreted by PaSC-ABCG2(+) cell population. The characterization of this secretome opens a new field of research involved in paracrine actions, such as inhibition of the proliferation and differentiation promotion in the ductal cell model.

\section{List of Abbreviations}

$\begin{array}{ll}\text { PaSC-ABCG2(+): } & \text { Pancreatic stellate cells } \\ \text { HpSC: } & \text { Hepatic stellate cells } \\ \text { RT-PCR: } & \begin{array}{l}\text { Reverse transcriptase-polymerase chain } \\ \text { reaction }\end{array} \\ & \text { Bromodeoxyuridine } \\ \text { BrdU: } & \begin{array}{l}\text { 3-(4,5-Dimethylthiazol-2-yl)-2,5- } \\ \text { diphenyl-2H-tetrazolium }\end{array} \\ \text { MTT: } & \text { bromide } \\ & \text { Bovine serum albumin } \\ \text { BSA: } & \text { Foetal calf serum } \\ \text { FCS: } & \text { Transforming growth factor } \beta \\ \text { TGF } \beta: & \text { Polysialic acid-neural cell adhesion } \\ \text { PSA-NCAM: } & \text { molecule } \\ \text { MALDI-TOF: } & \begin{array}{l}\text { Matrix assisted laser } \\ \text { desorption/ionization-time of flight }\end{array} \\ \text { 2D: } & \text { Two-dimensional electrophoresis. }\end{array}$

\section{Conflict of Interests}

The authors declare that they have no conflict of interests.

\section{Authors' Contribution}

Maria Lucas and Eugenia Mato contributed equally to this paper.

\section{Acknowledgments}

The authors thank Scientific and Technical Services of the Institute of Biomedical Research August Pi i Sunyer (IDIBAPS): Isabel Crespo (Flow Cytometry Unit) and Dr. Susana Kalko (Bioinformatics Unit). The authors thank Dr. Josep M Estanyol for MS analyses from the Proteomic Unit of SSR University of Barcelona and Dr. Eliandre Oliveira from
Proteomics Unit of Parc Científic de Barcelona for MALDITOF and MS/MS spectra acquisition. Proteomic Units are members of Spanish ProteoRed. They also would like to thank Yaiza Esteban for technical assistance in proteomics studies. This project was funded by grants from SAF200607382, RGDMG03/212, PI042553, PI020881, and RETIC RD06/0015/0002 and supported by Sardà Farriol Research Program. CIBER de Diabetes y Enfermedades Metabólicas Asociadas is an ISCIII project.

\section{References}

[1] M. V. Apte, P. S. Haber, S. J. Darby et al., "Pancreatic stellate cells are activated by proinflammatory cytokines: implications for pancreatic fibrogenesis," Gut, vol. 44, no. 4, pp. 534-541, 1999.

[2] M. B. Omary, A. Lugea, A. W. Lowe, and S. J. Pandol, "The pancreatic stellate cell: a star on the rise in pancreatic diseases," Journal of Clinical Investigation, vol. 117, no. 1, pp. 50-59, 2007.

[3] T. Knittel, S. Aurisch, K. Neubauer, S. Eichhorst, and G. Ramadori, "Cell-type-specific expression of neural cell adhesion molecule (N-CAM) in Ito cells of rat liver: up-regulation during in vitro activation and in hepatic tissue repair," American Journal of Pathology, vol. 149, no. 2, pp. 449-462, 1996.

[4] R. A. Hannivoort, S. Dunning, S. V. Borght et al., "Multidrug resistance-associated proteins are crucial for the viability of activated rat hepatic stellate cells," Hepatology, vol. 48, no. 2, pp. 624-634, 2008.

[5] E. Schneider, A. Schmid-Kotsas, J. Zhao et al., "Identification of mediators stimulating proliferation and matrix synthesis of rat pancreatic stellate cells," American Journal of Physiology-Cell Physiology, vol. 281, no. 2, pp. C532-C543, 2001.

[6] K. Shimizu, M. Kobayashi, J. Tahara, and K. Shiratori, "Cytokines and peroxisome proliferator-activated receptor $\gamma$ ligand regulate phagocytosis by pancreatic stellate cells," Gastroenterology, vol. 128, no. 7, pp. 2105-2118, 2005.

[7] P. A. Phillips, J. A. McCarroll, S. Park et al., "Rat pancreatic stellate cells secrete matrix metalloproteinases: implications for extracellular matrix turnover," Gut, vol. 52, no. 2, pp. 275-282, 2003.

[8] X. Xu, J. D’Hoker, G. Stangé et al., “ $\beta$ cells can be generated from endogenous progenitors in injured adult mouse pancreas," Cell, vol. 132, no. 2, pp. 197-207, 2008.

[9] S. Bonner-Weir, E. Toschi, A. Inada et al., "The pancreatic ductal epithelium serves as a potential pool of progenitor cells," Pediatric Diabetes, vol. 5, supplement 2, pp. 16-22, 2004.

[10] S. Bonner-Weir, M. Taneja, G. C. Weir et al., "In vitro cultivation of human islets from expanded ductal tissue," Proceedings of the National Academy of Sciences of the United States of America, vol. 97, no. 14, pp. 7999-8004, 2000.

[11] L. Bouwens and D. G. Pipeleers, "Extra-insular beta cells associated with ductules are frequent in adult human pancreas," Diabetologia, vol. 41, no. 6, pp. 629-633, 1998.

[12] E. Mato, M. Lucas, J. Petriz, R. Gomis, and A. Novials, "Identification of a pancreatic stellate cell population with properties of progenitor cells: new role for stellate cells in the pancreas," Biochemical Journal, vol. 421, no. 2, pp. 181-191, 2009.

[13] U. Rutishauser and L. Landmesser, "Polysialic acid in the vertebrate nervous system: a promoter of plasticity in cell-cell interactions," Trends in Neurosciences, vol. 19, no. 10, pp. 422427, 1996. 
[14] T. Ben-Hur, B. Register, K. Murray, G. Rougon, and M. DuboisDalcq, "Growth and fate of PSA-NCAM+ precursors of the postnatal brain," Journal of Neuroscience, vol. 18, no. 15, pp. 5777-5788, 1998.

[15] S. Barcelo-Batllori, H. Corominola, M. Claret, I. Canals, J. Guinovart, and R. Gomis, "Target identification of the novel antiobesity agent tungstate in adipose tissue from obese rats," Proteomics, vol. 5, no. 18, pp. 4927-4935, 2005.

[16] A. Shevchenko, M. Wilm, O. Vorm, and M. Mann, "Mass spectrometric sequencing of proteins from silver-stained polyacrylamide gels," Analytical Chemistry, vol. 68, no. 5, pp. 850-858, 1996.

[17] S. Barcelo-Batllori, M. Andre, C. Servis et al., "Proteomic analysis of cytokine induced proteins in human intestinal epithelial cells: implications for inflammatory bowel diseases," Proteomics, vol. 2, pp. 551-560, 2002.

[18] S. Barceló-Batllori, S. G. Kalko, Y. Esteban, S. Moreno, M. C. Carmona, and R. Gomis, "Integration of DIGE and bioinformatics analyses reveals a role of the antiobesity agent tungstate in redox and energy homeostasis pathways in brown adipose tissue," Molecular and Cellular Proteomics, vol. 7, no. 2, pp. 378393, 2008.

[19] J. D. Bendtsen, L. J. Jensen, N. Blom, G. von Heijne, and S. Brunak, "Feature-based prediction of non-classical and leaderless protein secretion," Protein Engineering, Design and Selection, vol. 17, no. 4, pp. 349-356, 2004.

[20] O. Emanuelsson, S. Brunak, G. von Heijne, and H. Nielsen, "Locating proteins in the cell using TargetP, SignalP and related tools," Nature Protocols, vol. 2, no. 4, pp. 953-971, 2007.

[21] G. Alvarez-Llamas, E. Szalowska, M. P. de Vries et al., "Characterization of the human visceral adipose tissue secretome," Molecular and Cellular Proteomics, vol. 6, no. 4, pp. 589-600, 2007.

[22] F. W.-T. Shek, R. C. Benyon, F. M. Walker et al., "Expression of transforming growth factor- $\beta 1$ by pancreatic stellate cells and its implications for matrix secretion and turnover in chronic pancreatitis," American Journal of Pathology, vol. 160, no. 5, pp. 1787-1798, 2002.

[23] H. Ohnishi, T. Miyata, H. Yasuda et al., "Distinct roles of smad2-, smad3-, and ERK-dependent pathways in transforming growth factor- $\beta 1$ regulation of pancreatic stellate cellular functions," Journal of Biological Chemistry, vol. 279, no. 10, pp. 8873-8878, 2004.

[24] J. Massague, S. Cheifetz, M. Laiho, D. A. Ralph, F. M. B. Weis, and A. Zentella, "Transforming growth factor- $\beta$," Cancer Surveys, vol. 12, pp. 81-103, 1992.

[25] S. S. Huang and J. S. Huang, "TGF- $\beta$ control of cell proliferation," Journal of Cellular Biochemistry, vol. 96, no. 3, pp. 447462, 2005.

[26] M. Kondo, E. Cubillo, K. Tobiume et al., "A role for Id in the regulation of TGF- $\beta$-induced epithelial-mesenchymal transdifferentiation," Cell Death and Differentiation, vol. 11, no. 10, pp. 1092-1101, 2004.

[27] M. Buchholz, H. A. Kestler, K. Holzmann et al., "Transcriptome analysis of human hepatic and pancreatic stellate cells: organspecific variations of a common transcriptional phenotype," Journal of Molecular Medicine, vol. 83, no. 10, pp. 795-805, 2005.

[28] A. M. Gressner, "The cell biology of liver fibrogenesis-an imbalance of proliferation, growth arrest and apoptosis of myofibroblasts," Cell and Tissue Research, vol. 292, no. 3, pp. 447452, 1998.
[29] H. Steiling, M. Muhlbauer, F. Bataille, J. Schölmerich, S. Werner, and C. Hellerbrand, "Activated hepatic stellate cells express keratinocyte growth factor in chronic liver disease," The American Journal of Pathology, vol. 165, pp. 1233-1241, 2004.

[30] R. J. Thomas, R. Bhandari, D. A. Barrett et al., "The effect of three-dimensional co-culture of hepatocytes and hepatic stellate cells on key hepatocyte functions in vitro," Cells Tissues Organs, vol. 181, no. 2, pp. 67-79, 2006.

[31] H. Nagai, K. Terada, G. Watanabe et al., "Differentiation of liver epithelial (stem-like) cells into hepatocytes induced by coculture with hepatic stellate cells," Biochemical and Biophysical Research Communications, vol. 293, no. 5, pp. 1420-1425, 2002.

[32] X. Xu, J. D’Hoker, G. Stangé et al., “ $\beta$ cells can be generated from endogenous progenitors in injured adult mouse pancreas," Cell, vol. 132, no. 2, pp. 197-207, 2008.

[33] S. Yatoh, R. Dodge, T. Akashi et al., "Differentiation of affinitypurified human pancreatic duct cells to $\beta$-cells," Diabetes, vol. 56, no. 7, pp. 1802-1809, 2007.

[34] H. Aoki, H. Ohnishi, K. Hama et al., "Existence of autocrine loop between interleukin- 6 and transforming growth factor$\beta 1$ in activated rat pancreatic stellate cells," Journal of Cellular Biochemistry, vol. 99, no. 1, pp. 221-228, 2006.

[35] S. G. Rane, J.-H. Lee, and H.-M. Lin, "Transforming growth factor- $\beta$ pathway: role in pancreas development and pancreatic disease," Cytokine and Growth Factor Reviews, vol. 17, no. 1-2, pp. 107-119, 2006.

[36] C. Kordes, S. Brookmann, D. Häussinger, and H. KlonowskiStumpe, "Differential and synergistic effects of platelet-derived growth factor-BB and transforming growth factor- $\beta 1$ on activated pancreatic stellate cells," Pancreas, vol. 31, no. 2, pp. 156167, 2005.

[37] M. V. Apte, P. S. Haber, T. L. Applegate et al., "Periacinar stellate shaped cells in rat pancreas: identification, isolation, and culture," Gut, vol. 43, no. 1, pp. 128-133, 1998.

[38] M.-L. Kruse, P. B. Hildebrand, C. Timke, U. R. Fölsch, and W. E. Schmidt, "TGF $\beta 1$ autocrine growth control in isolated pancreatic fibroblastoid cells/stellate cells in vitro," Regulatory Peptides, vol. 90, no. 1-3, pp. 47-52, 2000.

[39] C. Zhu, D. Ying, D. Zhou et al., "Expression of TGF-betal in smooth muscle cells regulates endothelial progenitor cells migration and differentiation," Journal of Surgical Research, vol. 125, no. 2, pp. 151-156, 2005.

[40] F. Han, C. S. Adams, Z. Tao et al., "Transforming growth factor- $\beta 1$ (TGF- $\beta 1$ ) regulates ATDC 5 chondrogenic differentiation and fibronectin isoform expression," Journal of Cellular Biochemistry, vol. 95, no. 4, pp. 750-762, 2005.

[41] F. Sanvito, P.-L. Herrera, J. Huarte et al., "TGF- $\beta 1$ influences the relative development of the exocrine and endocrine pancreas in vitro," Development, vol. 120, no. 12, pp. 3451-3462, 1994.

[42] E. Tei, S. Mehta, S. S. Tulachan et al., "Synergistic endocrine induction by GLP-1 and TGF- $\beta$ in the developing pancreas," Pancreas, vol. 31, no. 2, pp. 138-141, 2005.

[43] S. P. Becerra, "Structure-function studies on PEDF: a noninhibitory serpin with neurotrophic activity," Advances in Experimental Medicine and Biology, vol. 425, pp. 223-237, 1997.

[44] J. Tombran-Tink, G. G. Chader, and L. V. Johnson, "PEDF: a pigment epithelium-derived factor with potent neuronal differentiative activity," Experimental Eye Research, vol. 53, no. 3, pp. 411-414, 1991. 
[45] F. R. Steele, G. J. Chader, L. V. Johnson, and J. Tombran-Tink, "Pigment epithelium-derived factor: neurotrophic activity and identification as a member of the serine protease inhibitor gene family," Proceedings of the National Academy of Sciences of the United States of America, vol. 90, no. 4, pp. 1526-1530, 1993.

[46] C. Ramírez-Castillejo, F. Sánchez-Sánchez, C. Andreu-Agulló et al., "Pigment epithelium-derived factor is a niche signal for neural stem cell renewal," Nature Neuroscience, vol. 9, no. 3, pp. 331-339, 2006.

[47] J. Tombran-Tink, K. Mazuruk, I. R. Rodriguez et al., "Organization, evolutionary conservation, expression and unusual Alu density of the human gene for pigment epithelium-derived factor, a unique neurotrophic serpin," Molecular Vision, vol. 2, p. 11, 1996.

[48] R. S. Heller, T. Klein, Z. Ling et al., "Expression of Wnt, frizzled, sFRP, and DKK genes in adult human pancreas," Gene Expression, vol. 11, no. 3-4, pp. 141-147, 2003.

[49] A. Kanazawa, S. Tsukada, A. Sekine et al., "Association of the gene encoding wingless-type mammary tumor virus integration-site family member 5B (WNT5B) with type 2 diabetes," American Journal of Human Genetics, vol. 75, no. 5, pp. 832-843, 2004.

[50] W. J. Cho, E. J. Kim, S. J. Lee, H. D. Kim, H. J. Shin, and W. K. Lim, "Involvement of SPARC in in vitro differentiation of skeletal myoblasts," Biochemical and Biophysical Research Communications, vol. 271, no. 3, pp. 630-634, 2000.

[51] J. D. Mott and Z. Werb, "Regulation of matrix biology by matrix metalloproteinases," Current Opinion in Cell Biology, vol. 16, no. 5, pp. 558-564, 2004.

[52] L. Bugga, R. A. Gadient, K. Kwan, C. L. Stewart, and P. H. Patterson, "Analysis of neuronal and glial phenotypes in brains of mice deficient in leukemia inhibitory factor," Journal of Neurobiology, vol. 36, pp. 509-524, 1998.

[53] M. Nakanishi, T. Niidome, S. Matsuda, A. Akaike, T. Kihara, and H. Sugimoto, "Microglia-derived interleukin-6 and leukaemia inhibitory factor promote astrocytic differentiation of neural stem/progenitor cells," European Journal of Neuroscience, vol. 25, no. 3, pp. 649-658, 2007.

[54] L. Baeyens, S. de Breuck, J. Lardon, J. K. Mfopou, I. Rooman, and L. Bouwens, "In vitro generation of insulin-producing beta cells from adult exocrine pancreatic cells," Diabetologia, vol. 48, no. 1, pp. 49-57, 2005.

[55] W. Nickel, "Unconventional secretory routes: direct protein export across the plasma membrane of mammalian cells," Traffic, vol. 6, no. 8, pp. 607-614, 2005.

[56] D. Bach Kristensen, N. Kawada, K. Imamura et al., "Proteome analysis of rat hepatic stellate cells," Hepatology, vol. 32, no. 2, pp. 268-277, 2000. 

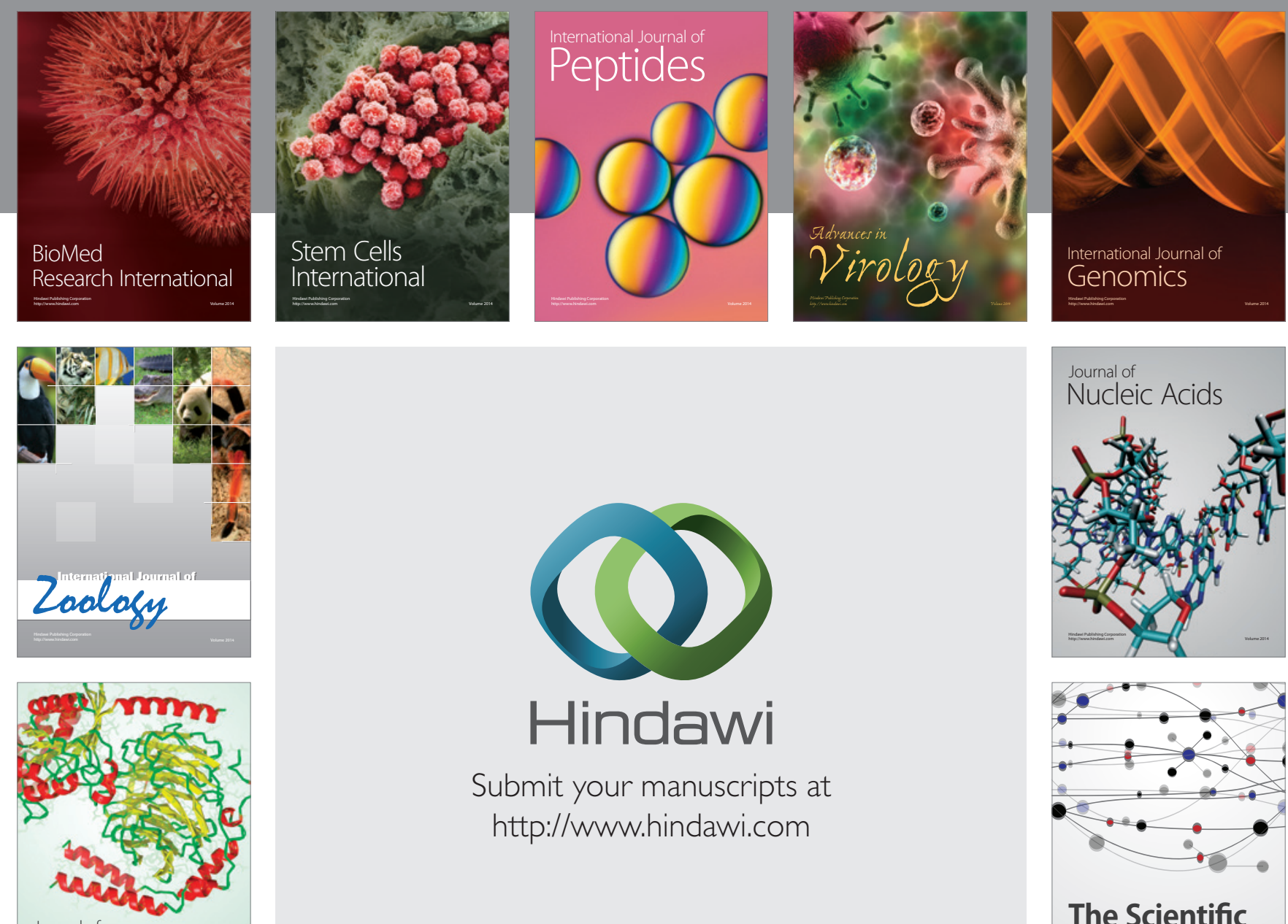

Submit your manuscripts at

http://www.hindawi.com

Journal of
Signal Transduction
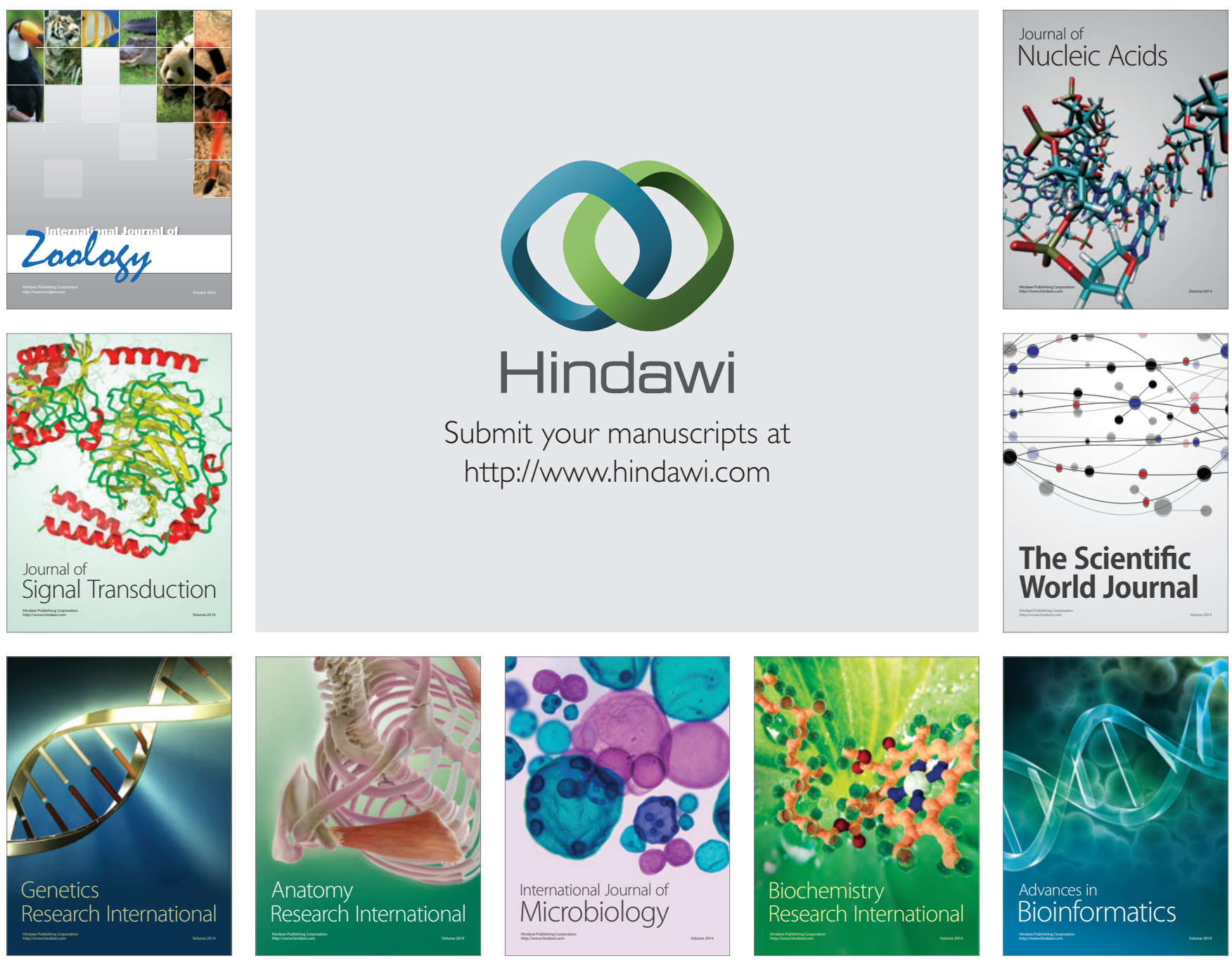

The Scientific World Journal
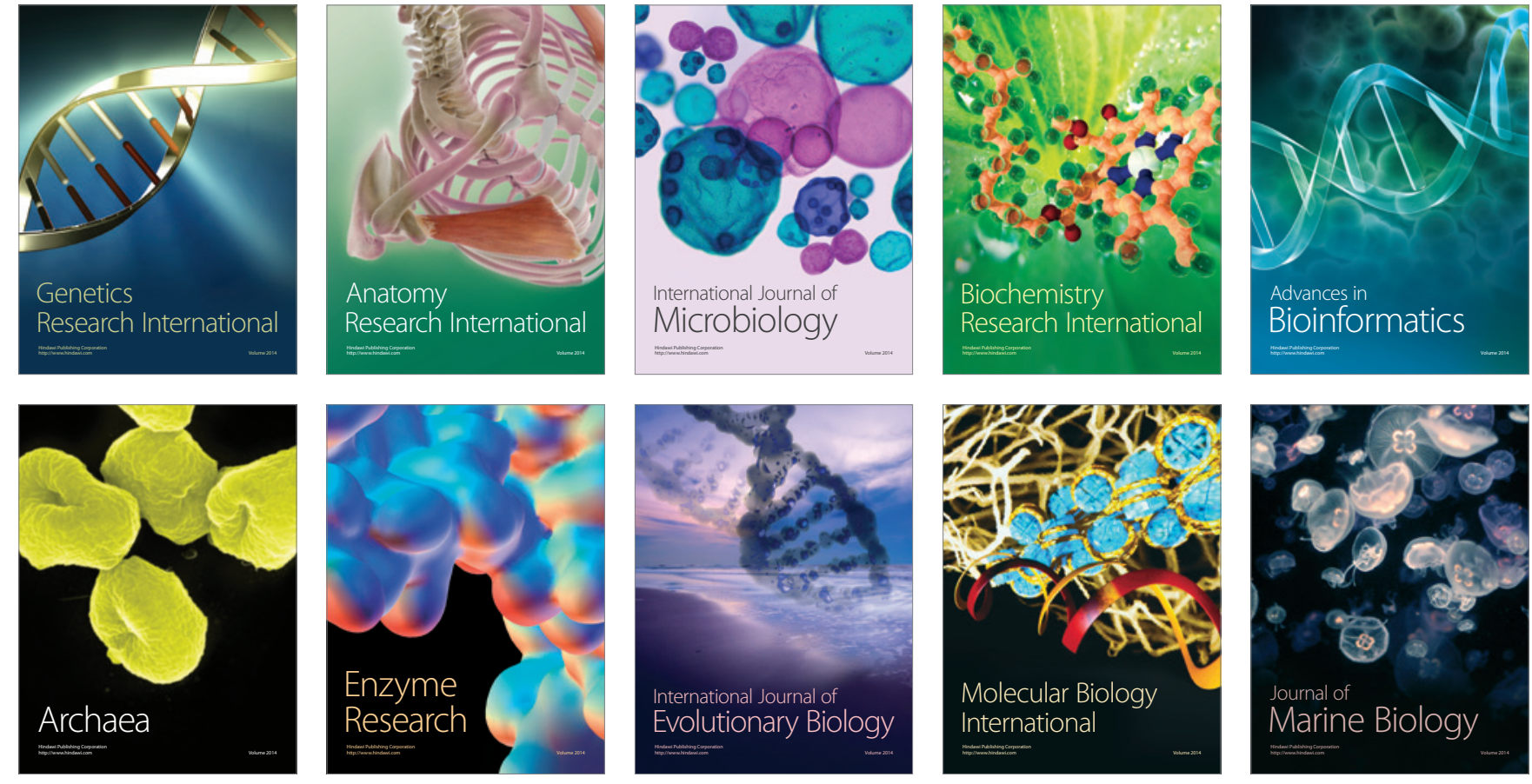